\title{
Rumen microbial protein flow and plasma amino acid concentrations in early lactation multiparity Holstein cows fed commercial rations, and some relationships with dietary nutrients.
}

\author{
N. Swanepoel ${ }^{\mathrm{a}, \mathrm{b}^{*}}$, P.H. Robinson ${ }^{\mathrm{b}}$, L.J. Erasmus ${ }^{\mathrm{a}}$ \\ ${ }^{a}$ Department of Animal and Wildife Sciences, University of Pretoria, 0001, South Africa \\ ${ }^{b}$ Department of Animal Science, University of California, Davis, CA, 95616, USA
}

* Corresponding author. Mobile: +27 798918920 ;

Email: nanswanepoel@gmail.com

\section{Highlights}

- 20 Commercial dairy farms fed a range of California early lactation rations.

- Data documents ranges of microbial protein outflow and plasma amino acid concentrations.

- Procedures provide a real time database as a benchmark for comparisons.

- Data provides guidelines for evaluation of diet formulations using models.

- Data can be used to identify rumen microbial growth and/or absorbable amino acid issues.

\begin{abstract}
Common contemporary diet formulation methods involve factorial or empirical models which simulate ruminal fermentation and post ruminal absorption to predict nutrient supply and needs. However, due to their inability to encompass all animal factors that affect digestion and absorption, metabolic models inadequately predict microbial protein (MCP) synthesis in the rumen and passage of nutrients such as protein and amino acids (AA) to the small intestine. Practical and simple on-farm methods to obtain "real time" values directly from cows are required to establish normal ranges of MCP flow from the rumen and plasma AA concentrations
\end{abstract}


on commercial dairy farms. Urine purine derivative (PD) output, an index of MCP supply to the intestine when analyzed in spot urine samples, can accurately predict MCP flow from the rumen under farm conditions. Blood sampling from the tail vein is easily performed on commercial dairy farms and concentrations of free AA in these plasma samples, representative of intestinally absorbed AA, can be used as an index to predict limiting AA. A group of 20 commercial dairy farms, milking $2677 \pm 372$ cows either 2 or 3 times a day were selected and one of their early lactation pens holding $255 \pm 20$ cows were used to represent the range of nutritional strategies and rations fed to California dairy cows. On the day of sampling, one load of early lactation total mixed ration (TMR) was sampled and 20 pre-selected cows were body condition scored (BCS). Directly after scoring, the 4 cows with the highest, and the 4 cows with the lowest BCS values were removed to collect 12 tail vein blood samples from the group with average BCS scores. Spot urine samples were collected from all voluntarily urinating cows (retaining 6 to 12 samples/pen to match the characteristics of the cows pre-selected for BCS scoring and blood sampling). Most rations contained alfalfa hay, corn silage, almond hulls, corn dried distillers grains, corn grain, cottonseed, canola meal (solvent) and a mineral premix. Selected cow groups produced $45 \pm 1.2 \mathrm{~kg}$ milk/day at $73 \pm 0.5$ days in milk with a BCS of $2.6 \pm 0.04$ at 2.8 lactations. There were no correlations between MCP and milk production, but MCP flow from the rumen was correlated to organic matter and neutral detergent fiber content of the TMR ( $P<0.01$ and $P=0.03$ respectively). Plasma AA concentrations were correlated with rumen undegradable crude protein (CP) and starch content of the TMR, with many inter-correlations among AA, but no plasma AA concentration was correlated to milk production. Results show that 8 urine samples and 6 blood samples/group provided accurate representation of the group. This study documents ranges of MCP flowing from the rumen $(1703 \pm 54.6 \mathrm{~g} \mathrm{CP} /$ day $)$, and plasma AA levels (with low variation within AA), in early lactation multiparity Holstein cows 
fed a range of contemporary dairy rations with multiple ingredient profile combinations. Since farms selected were well managed operations with cow groups selected to represent averages in early lactation, this data can be used as a benchmark for high, low and mean levels of MCP flow, and plasma AA concentrations, as well as provide real time evaluation of rations to identify possible rumen microbial growth and/or absorbable AA issues in commercial dairy cows.

Keywords: plasma amino acids; spot urine allantoin; microbial protein; total mixed rations

Abbreviations: AA, amino acid; AL, allantoin; BCS, body condition score; BW, body weight; $\mathrm{CM}$, canola meal; $\mathrm{CP}$, crude protein; DIM, days in milk; $\mathrm{DM}$, dry matter; $\mathrm{dNDF}_{30}, 30$ h in vitro NDF digestibility; EAA, essential AA; MCP, microbial CP; MP, metabolizable protein; NDF, neutral detergent fiber; NEAA, non-essential AA; NSC, non-structural carbohydrates; OM, organic matter; PD, purine derivatives; PDV, portally-drained viscera; RDP, rumen degradable CP; RUP, rumen undegradable CP; SG, specific gravity; TMR, total mixed ration.

List of AA abbreviations: Aspartic acid (Asp), Threonine (Thr), Serine (Ser), Glutamic acid (Glu), glycine (Gly), Alanine (Ala), Valine (Val), Methionine (Met), Isoleucine (Ile), Leucine (Leu), Tyrosine (Tyr), Phenylalanine (Phe), Tryptophan (Trp), Histidine (His), Arginine (Arg), Proline (Pro).

\section{Introduction}

It is widely acknowledged that dairy cattle must be fed nutritionally balanced rations to enhance microbial protein (MCP) production as well as to deliver intestinally absorbable protein with appropriate balances of specific amino acids (AA) to the small intestine. However, the required levels of MCP and most AA that should be targeted remain unclear. 
Traditional invasive methods to determine MCP production and absorbable protein delivery to the small intestine are complicated, expensive, time consuming, relatively imprecise and have unknown accuracy (reviewed by Clark et al., 1992). Therefore the most common method of formulating rations currently involves factorial or empirical models which simulate ruminal fermentation and predict duodenal protein flow. However, they inadequately predict MCP synthesis and degradability of protein in the rumen and passage of crude protein $(\mathrm{CP})$ and AA to the intestine (Bateman et al., 2001a,b; Hannigan et al., 2001). Even though a recent data analysis reported that a metabolic model predicted duodenal essential AA (EAA) flows are sufficiently accurate to balance for EAA in dairy rations in field conditions (Pacheco et al., 2012), it confirmed that the models are less accurate in low concentrate rations and rations not based on corn silage and alfalfa. Also, errors in predicted AA composition of MCP and digestibility of MCP in recently updated models lead to incorrect predictions of duodenal EAA availability and MCP flow (Patton et al., 2010). It was also reported (Lee et al., 2015) that efficiencies of utilization of AA for milk protein are likely overestimated by models due to overestimation of maintenance AA requirements and the continued assumption that efficiency of AA utilization for milk protein synthesis is constant (Doepel et al., 2004), leading to overfeeding of dietary N. Most metabolic models still do not allow for additive EAA effects but abide by the single limiting AA theory, which is incorrect (Arriola Apelo et al., 2014a, b). Other limitations of current models, such as the Cornell Net Protein and Carbohydrate System, are that they are CP based even though analyzed $\mathrm{CP}$ values do not account for all available $\mathrm{N}$ among feeds, as well as the general failure to acknowledge the contribution of endogenous protein to metabolizable protein (MP) supply. Since models cannot yet replace observations from cows, improvement in efficiency of protein utilization by commercial dairy cows requires development of alternative methods to augment metabolic models by determining and monitoring MCP supply, as well as facilitating 
further development of descriptors to better predict feed interactions and the underlying biology of lactating dairy cows.

Since specific AA requirements for ruminants are not well defined, they are generally estimated based on research with non-ruminants and/or assumed to be similar to the AA content of milk protein (Schingoethe, 1996), but little data is available to substantiate these assumptions and limited attempts to establish ideal concentrations of EAA in MP have not been successful (Fraser et al., 1991; as referenced by Rulquin and Verite 1993; Doepel et al., 2004). Interpreting results from experimental treatments by utilizing plasma AA levels (e.g., Swanepoel et al., 2014) amongst different rations can highlight changes and suggest AA limitations amongst treatments, but it does not relate experimental plasma AA concentrations to concentrations that would occur when cows are fed contemporary rations formulated under commercial conditions, which is often driven by animal production.

In light of difficulties in using models to predict limitations of MCP and plasma AA concentrations, as well as the lack of available conventional (i.e., non-experimental) plasma data, there is a need for practical and simple on-farm methods to estimate real time MCP flow from the rumen and plasma AA concentrations directly from cows. This will allow better evaluation of commercial dairy rations balanced for higher intestinal MCP and AA delivery by establishing normal ranges under conventional commercial conditions using contemporary rations. Thus this study used multiparity cows fed a range of contemporary early lactation dairy rations in California (USA), in order to determine normal ranges of MCP flow from the rumen, and plasma AA concentrations, in early lactation Holstein cows, as well as how many samples were required to represent these groups. This data was used to benchmark high, low and mean levels in samples collected using sampling methods possible under commercial conditions in order to assist evaluation of commercial rations, and to create a reference database to help others interpret 
the biological meaning of concentrations of these parameters under commercial and experimental conditions.

\section{Materials and methods}

\subsection{Farm, management and experimental design}

The study took place over 3 months in fall 2013. A group of commercial dairy farms in California were identified and, from this group, 24 dairy farm co-operators were selected to participate (Table 1). In order to ensure a representative range of MCP and plasma AA values, the farms represented all major dairy counties in California, were fed a wide range of rations and had consulting nutritionists. Other required factors included use of a computerized herd record and management system, a computerized ration mixing and feeding program, monthly milk tests through county or private testing companies, having a pen of at least 150 early lactation multiparity cows, and having generally good dairy management. Each farm was visited prior to the day of sampling to determine the location of one of their early lactation pens and obtain a backup copy of their herd management files, which were used to create lists of eligible cows prior to sampling (as described below). Of the 24 dairy farms, 4 failed to provide all of this data and were not included in the final data set. 
Table 1. Some characteristics of the 20 dairy farms and the chemical composition of the total mixed rations (TMR) fed to the target pen of early lactation cows on the dairy sites.

\begin{tabular}{|c|c|c|}
\hline & Mean & SE \\
\hline \multicolumn{3}{|l|}{ Dairy characteristics } \\
\hline Total milking cows & 2677 & 371.9 \\
\hline Milkings/day & 2.5 & 0.11 \\
\hline Cows in target pen & 255 & 20.4 \\
\hline \multicolumn{3}{|c|}{ TMR chemical components $(\mathrm{g} / \mathrm{kg} D M)$} \\
\hline Dry matter $(\mathrm{DM} ; \mathrm{g} / \mathrm{kg})$ & 577 & 12.0 \\
\hline Organic matter $(\mathrm{OM})$ & 914 & 2.3 \\
\hline Crude protein $(\mathrm{CP})$ & 165 & 2.3 \\
\hline Soluble $\mathrm{CP}^{1}$ & 281 & 10.7 \\
\hline Degradable $\mathrm{CP}^{2}$ & 506 & 14.6 \\
\hline Starch & 198 & 9.2 \\
\hline Crude Fat & 47 & 1.9 \\
\hline $\mathrm{NDF}^{3}$ & 299 & 5.1 \\
\hline $\mathrm{dNDF}_{30}^{4}$ & 459 & 9.8 \\
\hline $\mathrm{NSC}^{5}$ & 403 & 5.9 \\
\hline \multicolumn{3}{|c|}{ Gas Production (ml/g OM) @ hours of incubation: } \\
\hline $4 \mathrm{~h}$ & 102 & 1.2 \\
\hline $24 \mathrm{~h}$ & 264 & 3.4 \\
\hline $30 \mathrm{~h}$ & 278 & 3.4 \\
\hline $48 \mathrm{~h}$ & 296 & 3.7 \\
\hline
\end{tabular}

${ }^{1}$ Expressed as g/kg CP as buffer soluble CP (Krishnamoorthy et al., 1982).

${ }^{2}$ Calculated as 100 minus undegraded CP from Streptomyces griseus procedure (Krishnamoorthy et al., 1983).

${ }^{3}$ Neutral detergent fiber assayed with heat stable amylase, expressed exclusive of residual ash.

${ }_{5}^{4} 30 \mathrm{~h}$ ruminal in vitro NDF digestibility ( $\left./ \mathrm{kg} \mathrm{NDF}\right)$.

${ }^{5}$ Non structural carbohydrates calculated as 100 minus Ash, Fat, CP, NDF (g/kg DM).

\subsection{Sample collection, preparation and analytical methods}

\subsubsection{Total mixed ration}

On the day of sampling, a load of total mixed ration (TMR) fed to the target early lactation pen was sampled by taking 10 handfuls at evenly spaced intervals along the bunk-line immediately after feeding, but before the cows had access to it, and immediately sub-sampled to create a representative sample (Robinson and Meyer, 2010). These TMR samples were frozen until chemical analysis. The ingredient profiles of the TMR $(\mathrm{g} / \mathrm{kg}$ dry matter; DM) for the target early lactation pen on each of the farms was obtained from the dairy farmer or nutritionist. 
All TMR samples were weighed, dried at $55^{\circ} \mathrm{C}$ for $48 \mathrm{~h}$, and allowed to air equilibrate at room temperature for $24 \mathrm{~h}$ to determine air equilibrated DM before chemical analysis. All samples were ground to pass a $1 \mathrm{~mm}$ screen on a model 4 Wiley Mill (Thomas Scientific, Swedesboro, NJ, USA). Oven DM of the air equilibrated samples were determined as the gravimetric loss when dried at $105^{\circ} \mathrm{C}$ for $3 \mathrm{~h}$ in a forced air oven (NFTA, 2006). Ash determination was based on gravimetric loss by heating samples to $550^{\circ} \mathrm{C}$ for at least $3 \mathrm{~h}$ (\#942.05; AOAC, 2005). Total $\mathrm{N}$ was determined by a Leco method (\#990.03; AOAC, 2005). Neutral detergent fiber (NDF) was expressed without ash and determined using neutral detergent (\#2002.04; AOAC, 2006) with heat-stable amylase used to remove starch and inactivate enzymes that may degrade the NDF. Fat was quantified using the Randall modification of the standard Soxhlet extraction (\#2003.05; AOAC, 2006) and starch was determined as total glucose minus free glucose multiplied by 0.9 (Smith, 1969). Rumen degradable CP analysis, in which all TMR were subjected to rumen proteolytic simulation for $48 \mathrm{~h}$ (chosen to create a comparative index of potential degradability of $\mathrm{CP}$ in the TMR), in a protease solution containing enzymes from Streptomyces griseus was the measure of undegraded CP (Krishnamoorthy et al., 1983). Soluble CP was analysed using the borate-phosphate procedure of Krishnamoorthy et al. (1982) and $30 \mathrm{~h}$ ruminal in vitro $\mathrm{NDF}$ digestibility $\left(\mathrm{dNDF}_{30}\right)$ was measured according to Robinson et al. (1999) with the exception that in vitro baths (Menke and Steingass, 1988) were used instead of the DAISY ${ }^{\circledR}$ Ankom system. Syringes containing $200 \mathrm{mg}$ of sample were incubated in water baths for $30 \mathrm{~h}$ without releasing gas. The $48 \mathrm{~h}$ in vitro gas production procedure was completed according to Menke and Steingass (1988) using two dry cows as rumen fluid donors with duplicate syringes per TMR sample. Gas production at $4 \mathrm{~h}$ of incubation was accepted as indicative of fermentation of non-structural carbohydrates (NSC) immediately available to microorganisms in the rumen (Cone et al., 1997) while $24 \mathrm{~h}$ incubations are used to predict metabolizable energy as in the 
original Menke and Steingass (1988) publication. The $30 \mathrm{~h}$ incubation values allow for comparison with $\mathrm{dNDF}_{30}$ procedures, and the $48 \mathrm{~h}$ incubation values reflect the time recommended in NRC (2001) to estimate the net energy of feedstuffs.

\subsubsection{Animal measurements}

A group of 20 cows was selected from the target early lactation pens, including only multiparity cows, to average 75 days in milk (DIM) and exclude cows in lactation 5 or higher due to low numbers. Milk yields from the cows were obtained from county or private company milk recordings after each farm's routine monthly milk test which had occurred within 4 days of sampling. Daily milk production was estimated for each cow by multiplying the yield recorded on individual portable milk meters by three (in the case of $3 \mathrm{x}$ milking herds) or by combining the milk yields recorded at two milkings (in the case of 2x milking herds).

Body condition scoring (BCS) was completed on all 20 cows within each group by the same trained scorer using the 5 point BCS system of Ferguson et al. (1994), which defines quarter points based upon anatomical characteristics of the cows. However, when a cow demonstrated characteristics which made it difficult to clearly classify her to a specific quarter point (e.g., 2.00 versus 2.25), she was classed as intermediate.

After removal of the 4 cows with the highest, and the 4 cows with the lowest, BCS values immediately after scoring the 20 cows, blood was collected from the tail (coccygeal) vein of the remaining 12 cows using a $10 \mathrm{ml}$ evacuated tube containing $\mathrm{K}_{2}$ EDTA (Vacutainer, Becton Dickinson, Franklin Lakes, NJ, USA), kept in foam coolers with ice and centrifuged within $3 \mathrm{~h}$ at $2100 x \mathrm{~g}$ for $15 \mathrm{~min}$ at $4^{\circ} \mathrm{C}$. Plasma was removed, transferred to duplicate Eppendorf tubes and frozen at $-20^{\circ} \mathrm{C}$ until a set of 7 samples/dairy was sent for analysis of physiological AA (i.e., free plasma AA) and ammonia. Samples were acidified with sulfosalicyclic acid to precipitate intact 
proteins and AA quantified using a Beckman 6300 AA analyzer (Beckman Coulter, Inc., La Brea, CA, USA) with a lithium citrate buffer system and ion-exchange chromatography to separate AA followed by a "post-column" ninhydrin reaction detection system.

Spot urine samples were collected from any cow in the target pen which voluntarily urinated during the morning lockup for normal health and reproductive checks ( $\sim 50 \mathrm{~min} / \mathrm{pen} / \mathrm{day})$ and immediately placed in ice. However samples were only retained if cows adhered to the same specifications listed above for blood collection cows (i.e., multiparity, lactation 5 or lower), except that the DIM range for urine was expanded to be 38 to 151 DIM. This resulted in each dairy having a group of 6 to 12 cows which met the criteria for target urine samples. The specific gravity (SG) of each untreated urine sample was measured within 90 min using a digital refractometer (Atago USA Inc., Bellevue, WA, USA) to estimate urine volume (as described below). A small quantity of urine $(7 \mathrm{ml})$ was combined with $1.4 \mathrm{ml}$ of $100 \mathrm{ml} / \mathrm{L}$ sulphuric acid to reduce the final $\mathrm{pH}$ to $<3$ in order to prevent bacterial destruction of allantoin (AL), diluted with water to a final volume of $35 \mathrm{ml}$ and frozen at $-20^{\circ} \mathrm{C}$. Urine samples were chemically analyzed for AL according to Chen and Gomes (1992). Standards were prepared to create working concentrations of 20,40,60, 80 and $100 \mathrm{mg} \mathrm{AL/L.} \mathrm{Urine} \mathrm{samples} \mathrm{were} \mathrm{thawed} \mathrm{and}$ centrifuged at $1200 \mathrm{xg}$ for $15 \mathrm{~min}$ at 20 to $22^{\circ} \mathrm{C}$ in order to remove precipitate which could influence the colorimetric reading and diluted 60 times to fit the standard curve. A duplicate standard curve was included at the start and end of each run to calculate AL concentrations in the urine samples which, with estimated urine volume, was used to calculate flow of MCP from the rumen to the small intestine. Two inter-run standard samples were used in each run and the average concentration of the inter-run standards in all runs was used to correct sample concentrations in each run. Each urine sample was analyzed in duplicate. 


\subsection{Calculations}

Final oven DM was calculated as air equilibrated DM (i.e., dried at $55^{\circ} \mathrm{C}$ and air equilibrated for $24 \mathrm{~h}$ ) multiplied by the laboratory oven $\mathrm{DM}$ (i.e., dried at $105^{\circ} \mathrm{C}$ ) of the air equilibrated sample. Gas production (ml/g organic matter; OM) of the TMR samples at various times (i.e., 4, 24, 30 and $48 \mathrm{~h}$ ) were determined using the method of Robinson et al. (2004), and calculated as:

((Sample gas production/h since last recording) - (Blank gas production/h since last recording)) / (TMR laboratory oven DM, g/kg) / (TMR OM, g/kg)

Urine volume (L/day) was calculated using an equation derived from data of Burgos et al. (2005) utilizing early lactation Holstein cows as:

$$
332.66 *\left(((\mathrm{SG}-1) * 1000)^{-0.884}\right)
$$

Total daily purine derivative (PD) excretion (mmol/day) was calculated as the sum of PD excreted in urine and milk of lactating dairy cows (Chen and Gomes, 1992), assuming AL consisted 0.906 of total PD in urine (as calculated by Swanepoel et al., 2015) and PD excretion in milk was a constant 0.05 of urine PD excretion. Microbial purines absorbed from the intestine (X, mmol/day) were calculated using a constant assumed body weight (BW) of $675 \mathrm{~kg}$, as:

(Total daily $\left.\mathrm{PD}-0.385 \times\left(\mathrm{BW}^{0.75}\right)\right) / 0.85$,

assuming that the endogenous contribution of $\mathrm{PD}$ is $0.385 \mathrm{mmol} / \mathrm{kg} \mathrm{BW}^{0.75}$ and that 0.85 represents recovery of absorbed purines as PD in the urine.

Microbial CP production (g CP/day) was then estimated as:

$$
[(\mathrm{X}(\mathrm{mmol} / \mathrm{day}) \times 70) /(0.116 * 0.83 * 1000)] \times 6.25
$$

assuming an $\mathrm{N}$ content of $70 \mathrm{mg} \mathrm{N} / \mathrm{mmol}$ for purines, a ratio of purine $\mathrm{N}$ :total $\mathrm{N}$ in mixed rumen microbes as 11.6:100, a microbial purine digestibility of 0.83 and the conversion of microbial $\mathrm{N}$ to MCP by the factor 6.25 . 


\subsection{Statistical analysis}

Characteristics of the 20 dairy farms, analysis of the early lactation cow groups sampled for blood and urine on each farm as well as chemical and ingredient composition of the TMR $(n=$ 20 dairies) used dairy (pen) as the experimental unit and fixed effect in the GLM option of SAS (2012) to calculate average values for individual farms, followed by the descriptive statistics function in the data analysis tool pack of Excel 2013 to calculate mean and standard errors for dairy characteristics and analytes across all farms. Correlation analysis using the 20 pen means, utilizing backward elimination through the STEPWISE procedure of SAS (2012) was used to determine predictability of MCP and plasma AA concentrations on milk production and also from single analyte levels and ingredient profiles of TMR. The descriptive statistics function in the data analysis tool pack of Excel 2013 was also used to construct box-and-whisker plots with median, minimum, maximum, $20^{\text {th }}$ and $80^{\text {th }}$ percentile calculations for MCP and individual plasma AA concentrations. A least square difference (LSD) analysis was performed on urine MCP and plasma AA data to determine the lowest number of samples at which addition of more samples no longer reduced the LSD for the dataset (i.e., did not change the residual SE, data not shown). This was used as an indication of the number of samples required to give an accurate representation of the sample group. Fitting a linear trend line within Excel 2013 generated $r^{2}$ values to evaluate the magnitude and importance of correlations amongst nutrients and analytes. Since non-linear regressions were not significant, they were not included in the results section.

\section{Results}

\subsection{Dairy farms and total mixed ration characteristics}

Some characteristics of the dairy farms are in Table 1 . The farms milked $2677 \pm 372$ (SE) cows either 2 or 3 times a day with the target early lactation pen holding $255 \pm 20$ cows. The 
Table 2. Ingredient composition (g/kg TMR DM) of the total mixed rations (TMR) fed to the target pens of early lactation cows on the dairy sites.

\begin{tabular}{|c|c|c|c|}
\hline & $n^{1}$ & Mean $^{2}$ & SE \\
\hline \multicolumn{4}{|l|}{ Forages } \\
\hline Alfalfa, fresh chop & 2 & 37.4 & 0.09 \\
\hline Alfalfa, hay & 20 & 160 & 1.5 \\
\hline Alfalfa, haylage & 6 & 88.4 & 1.79 \\
\hline Cereal, hay & 3 & 21.1 & 0.49 \\
\hline Cereal, silage & 9 & 121 & 3.1 \\
\hline Corn, earlage & 2 & 167 & 9.0 \\
\hline Corn, silage & 16 & 161 & 1.2 \\
\hline Sorghum, silage & 4 & 64.3 & 1.26 \\
\hline Wheat, straw & 5 & 21.0 & 0.37 \\
\hline \multicolumn{4}{|l|}{ Plant by-products } \\
\hline Almond, hulls & 15 & 101 & 1.0 \\
\hline Brewers grains, wet & 4 & 37.0 & 1.14 \\
\hline Carrot, pomace/wet & 1 & 16.0 & - \\
\hline Citrus, pulp/wet & 6 & 13.6 & 0.43 \\
\hline Corn gluten, pellets & 4 & 60.6 & 0.65 \\
\hline Corn gluten, wet & 2 & 50.6 & 0.55 \\
\hline Cottonseed, hulls & 1 & 41.2 & - \\
\hline Corn distillers grains, dry & 11 & 78.9 & 0.84 \\
\hline Corn distillers grains, wet & 4 & 60.2 & 1.00 \\
\hline Pomegranate, pulp/wet & 1 & 33.1 & - \\
\hline Rice, bran & 2 & 59.6 & 0.38 \\
\hline Soybean, hulls & 2 & 48.4 & 2.32 \\
\hline Tomato wet, pomace & 2 & 38.1 & 1.29 \\
\hline Wheat, midds/millrun & 6 & 70.0 & 1.19 \\
\hline \multicolumn{4}{|c|}{ Grains, Whole seeds and Protein meals } \\
\hline Corn, grain & 19 & 187 & 1.1 \\
\hline Cottonseed, fuzzy upland & 15 & 73.6 & 0.54 \\
\hline Cottonseed, pima cracked & 5 & 44.9 & 0.85 \\
\hline Canola, expeller meal & 1 & 73.3 & - \\
\hline Canola, solvent meal & 19 & 77.8 & 0.85 \\
\hline Sunflower, expeller meal & 1 & 81.7 & - \\
\hline \multicolumn{4}{|l|}{ Minerals and premixes } \\
\hline Limestone & 2 & 6.15 & 0.195 \\
\hline Mineral, premix & 17 & 17.6 & 0.17 \\
\hline Sodium bicarbonate & 6 & 11.0 & 0.22 \\
\hline \multicolumn{4}{|l|}{ Miscellaneous } \\
\hline Bakery, waste & 3 & 44.5 & 2.11 \\
\hline Fat, animal & 1 & 13.5 & - \\
\hline Fat, vegetable & 1 & 5.46 & - \\
\hline Fat, rumen inert & 7 & 9.22 & 0.119 \\
\hline Molasses, liquid & 10 & 23.1 & 0.30 \\
\hline Whey, liquid & 10 & 30.6 & 0.34 \\
\hline Unidentified & 3 & 41.9 & 0.53 \\
\hline
\end{tabular}

${ }^{1}$ Number of dairies for which ingredient appeared in the TMR.

${ }^{2}$ Average inclusion level in the TMR which contained the ingredient. 
TMR fed to the 20 target early lactation pens were relatively consistent in chemical profile (Table 1) even though their ingredient profiles and inclusions (Table 2) varied considerably amongst farms. The CP, starch, fat and NDF of the TMR among dairies were $165 \pm 2.3,198 \pm$ 9.2, $47 \pm 1.9$ and $299 \pm 5.1 \mathrm{~g} / \mathrm{kg}$ respectively. This consistency of TMR chemical profiles suggests that the nutritional consultants formulated the diets to standards generally consistent with NRC (2001) guidelines, where appropriate. For example, CP and NDF levels in the TMR were within NRC (2001) recommended ranges, while fat levels (47.2 g/kg DM) were slightly higher than the NRC (2001) recommendation of 30 to $40 \mathrm{~g} / \mathrm{kg} \mathrm{DM}$.

Gas production at $4 \mathrm{~h}$ of incubation were $102 \pm 1.2 \mathrm{ml} / \mathrm{g} \mathrm{OM}$ with 24,30 and $48 \mathrm{~h}$ values of $264 \pm 3.4,278 \pm 3.4$ and $296 \pm 3.7$ respectively. These values tend to be slightly higher than values from Rauch et al. (2012) on dairy TMR, but the variability among TMR was generally low.

\subsection{Characteristics of cows in the blood and urine sample groups}

Average milk production for the blood and urine sample groups were similar at 45.1 and 44.4 $\mathrm{kg} /$ day respectively with relatively low variation amongst farms (Table 3), as expected since our cow groups were selected to be high producing cows in a narrow DIM range. The blood cow group BCS averaged 2.63 with low variation amongst farms. The difference in DIM between the blood and urine groups, with the urine group having a slightly higher average DIM of 89 compared to the average DIM of 73 (ranging 53 to 93 DIM) in the blood group was due to selection method prior to sampling, as blood cows were pre-selected to average 75 DIM prior to the sampling while urine cows were collected if they voluntarily urinated, and then post-selected to only retain urine from cows that were 38 to 151 DIM. 
Table 3. Characteristics and analysis of the early lactation cows sampled for blood and urine on the dairy sites.

\begin{tabular}{|c|c|c|c|c|}
\hline & \multicolumn{2}{|c|}{ Blood group ${ }^{1}$} & \multicolumn{2}{|c|}{ Urine group $^{2}$} \\
\hline & Mean & SE & Mean & SE \\
\hline \multicolumn{5}{|l|}{ Pen characteristics } \\
\hline Milk production (kg/day) & 45.1 & 1.25 & 44.4 & 1.20 \\
\hline Days in milk & 73.1 & 0.52 & 89.1 & 3.92 \\
\hline Lactation number & 2.8 & 0.08 & 2.8 & 0.09 \\
\hline $\mathrm{BCS}^{3}$ & 2.63 & 0.036 & - & - \\
\hline \multicolumn{5}{|l|}{ Urine analysis } \\
\hline Specific gravity $\left(\mathrm{g} / \mathrm{cm}^{3}\right)$ & & & 1.023 & 0.0007 \\
\hline Volume (L/day) & & & 23.1 & 1.06 \\
\hline Allantoin concentrations (mg/L) & & & 2445 & 101.7 \\
\hline Allantoin output (mmol/day) & & & 318.9 & 8.81 \\
\hline Microbial crude protein (CP; g/day) & & & 1703 & 54.6 \\
\hline \multicolumn{5}{|l|}{ Plasma analysis } \\
\hline \multicolumn{5}{|l|}{ Essential amino acids (EAA) } \\
\hline Lysine (Lys) & 10.6 & 0.33 & & \\
\hline Methionine (Met) & 3.54 & 0.099 & & \\
\hline Histidine (His) & 8.08 & 0.225 & & \\
\hline Phenylalanine (Phe) & 8.55 & 0.147 & & \\
\hline Leucine (Leu) & 21.7 & 0.67 & & \\
\hline Valine (Val) & 29.3 & 0.85 & & \\
\hline Isoleucine (Ile) & 14.1 & 0.38 & & \\
\hline Arginine (Arg) & 14.0 & 0.39 & & \\
\hline Threonine (Thr) & 13.1 & 0.46 & & \\
\hline Tryptophan (Trp) & 16.1 & 0.32 & & \\
\hline Total EAA & 139 & 3.9 & & \\
\hline \multicolumn{5}{|l|}{ Non-essential amino acids (NEAA) } \\
\hline Tyrosine (Tyr) & 10.6 & 0.29 & & \\
\hline Glutamine (Gln) & 54.6 & 1.27 & & \\
\hline Glutamic acid (Glu) & 8.07 & 0.313 & & \\
\hline Alanine (Ala) & 23.9 & 0.56 & & \\
\hline Serine (Ser) & 9.74 & 0.159 & & \\
\hline Glycine (Gly) & 26.9 & 0.73 & & \\
\hline Aspartic acid (Asp) & 1.25 & 0.088 & & \\
\hline Proline (Pro) & 12.0 & 0.26 & & \\
\hline Total NEAA & 147 & 3.7 & & \\
\hline Ammonia & 2.8 & 0.07 & & \\
\hline
\end{tabular}

${ }^{1} n=7$ for all dairies.

${ }^{2} n=12$ for all dairies, except $n=6$ for dairy $2 \& 13 . n=7$ for dairy $9 . n=9$ for dairy 1,8 and $15 . n=10$ for dairy 5 and $n=11$ for dairy 3 and 4 .

${ }^{1}$ Body condition score; Cows in the urine group were not BCS scored.

\subsection{Urine analysis of cows in the urine sample group}

The average urine SG of $1.02 \mathrm{~g} / \mathrm{cm}^{3}$, and estimated volume of $23 \mathrm{~L} /$ day (Table 3), is similar to ranges of SG and urine volume reported by Holter and Urban (1992) for early lactation 
Holstein cows determined by total urine collection, supporting use of SG to estimate urine volume. The average estimated MCP flow from the rumen, $1703 \mathrm{~g} \mathrm{CP/day}$ is in the range of previous studies in which MCP was directly measured in duodenal samples, as discussed by Swanepoel et al. (2015).

\subsection{Plasma amino acid levels of cows in the blood sample group}

Plasma AA levels $(\mu \mathrm{g} / \mathrm{ml})$, as averages, are in Table 3 with all AA having low variation, as indicated by the SE values, except for Asp which is more variable and consistent with our previous studies (Swanepoel et al., 2010a, 2014; Robinson et al., 2011).

\section{Discussion}

Overall, the main feeds in our early lactation TMR were similar to what has been used and fed in California over the last decade (e.g., Swanepoel et al., 2010b) even though their ingredient profiles and inclusions (Table 2) varied considerably amongst farms. Most TMR contained some form of alfalfa in addition to corn silage, almond hulls, corn grain, cottonseed and canola meal (CM), but there were numerous ingredients that were only used in a few rations (i.e., corn earlage, corn gluten pellets, wheat millrun, rice bran, carrot and tomato wet pomace, soybean meal, cottonseed hulls, pomegranate wet pulp, sunflower meal, bakery waste). This wide variation in the ingredient profiles of the TMR allowed us to meet our objective of a wide range of TMR.

The low average lactation number, 2.8, represents current replacement policies/practices on a large proportion of California dairy farms due to replacement cow costs being relatively low, increased use of sexed semen yielding higher proportions of heifers with desirable genetic potential in herds with little or no growth potential due to the local regulatory environment, and 
high beef prices, leading to high herd culling in order to prevent cows becoming sick (i.e., requiring expensive treatments) or dying on dairy farms. Since elevated plasma ammonia concentrations are generally accepted as an indication of sick cows, the generally low ammonia concentrations confirm that normal healthy cows were used in our study.

\subsection{Estimating rumen microbial CP production}

Estimating MCP synthesis in dairy cows requires accurate measurement of a marker entering the small intestine (intestinal cannulation) or passing out of the rumen (omasal cannulation). In order to determine the quality and quantity of protein available for digestion and absorption in the intestine, a number of measurements, usually based on microbial markers or predictions are required. These include ruminal degradation of protein (RDP) and AA in each feedstuff and its conversion into MCP as well as rumen passage of MCP, with its AA profile, to the lower tract, post-ruminal digestibility and absorption of $\mathrm{MCP}$, as well as metabolism of AA across gut tissues, portally-drained viscera (PDV) and liver. While methods to measure most of these parameters in vivo exist, they require cannulated animals and the measuring procedures are complicated, expensive, time consuming, imprecise and have unknown accuracy (Clark et al., 1992). The urgent need for on-farm methods to estimate real time MCP flow from the rumen has been suggested (e.g., Dewhurst et al., 1996) as an indication of rumen performance and as the basis for more informed feeding decisions by dairy farmers and advisors.

When microbial nucleic acids are digested in the intestine, the by-product PD, mainly AL, is excreted in the urine. Urine PD output has been shown to be an effective index of MCP supply to the intestine of lactating dairy cattle (Chen and Ørskov, 2004; González-Ronquillo et al., 2003; Chizzotti, et al., 2008). Even though total urine collection is not feasible under our commercial farm conditions, collecting spot urine samples is easily performed. Studies designed to evaluate 
accuracy of estimating PD output in urine have shown that PD excretion estimated by spot urine sampling is not different from total urine collection (Chizzotti et al., 2008), showing that spot urine samples can be used to accurately estimate MCP flow from the rumen under farm conditions. Chen and Ørskov (2004) suggested that variability of spot measurements is higher than for total collection, and that more measurements should be made to reduce errors. However, compared to previous studies in which duodenal samples were collected and MCP directly measured in duodenal chyme (Robinson et al., 1985, 1994, 1996a, 1996b, 1998; Khorasani et al., 1993, 1994; Stensig and Robinson, 1997), our technique of MCP estimation using urine AL analysis can be interpreted to correlate (Figure 1) with that technique, even though data obtained from the duodenally cannulated cows does not reflect contemporary milk production levels.

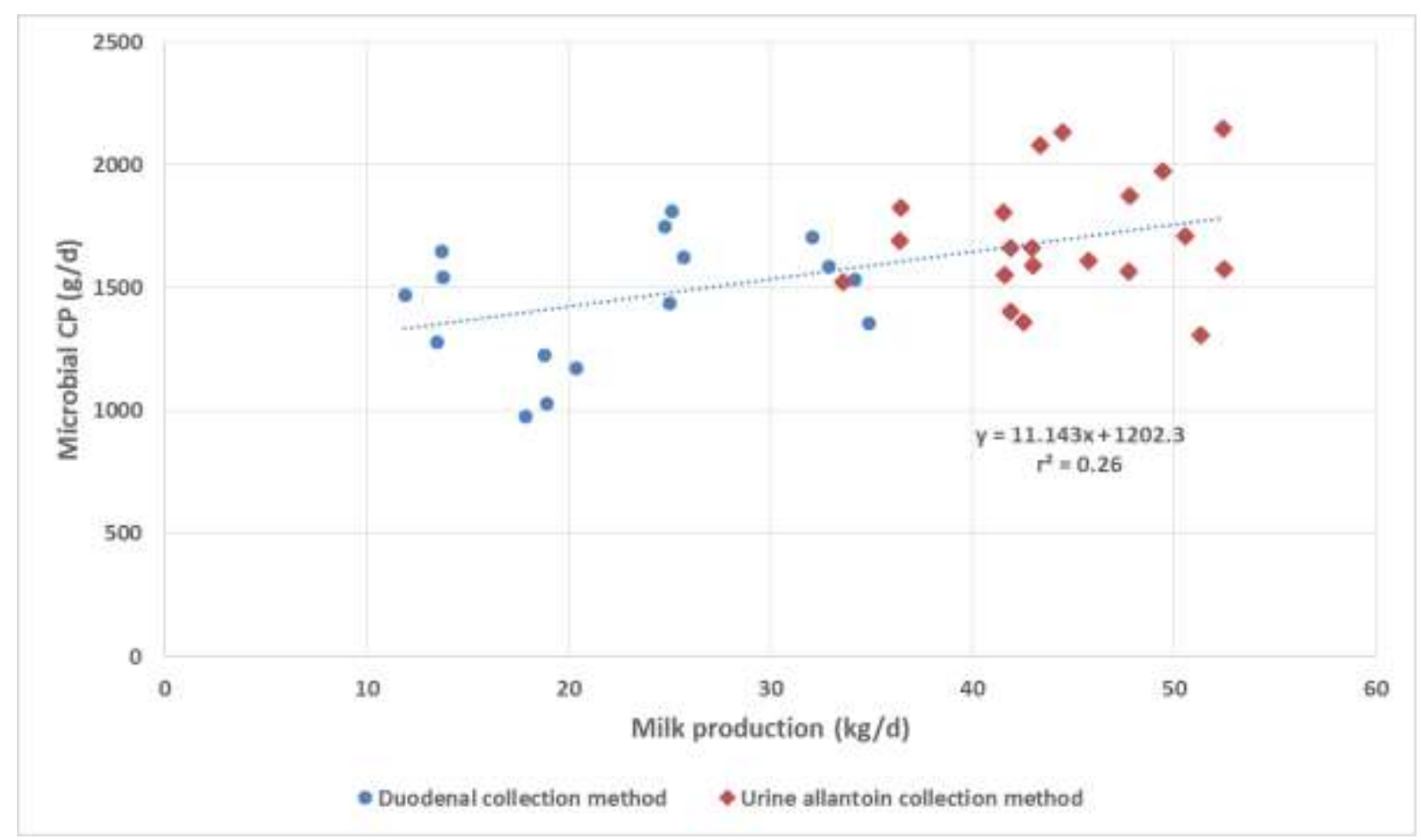

Figure 1. Microbial crude protein (MCP) flow from the rumen $(\mathrm{g} / \mathrm{d})$ as related to milk production $(\mathrm{kg} / \mathrm{d})$ for techniques using duodenally collected samples (Robinson et al., 1985, 1994, 1996a, 1996b, 1998; Khorasani et al., 1993, 1994; Stensig and Robinson, 1997) to analyze MCP (O) compared to the urine allantoin sampling technique ( ) from this study. 


\subsubsection{Ranges of estimated MCP flow from the rumen}

Using the LSD analysis described in section 2.4, results suggest that analyzing 8 urine samples/group is required to provide adequate representation of a group of cows. This number of 8 replicates/diet for spot urine samples was also suggested by Dewhurst et al. (1996), and Oetzel (2003) reported that at least 8 cows should be sampled for urine in order to have confidence that the mean values truly represent the entire population.

The normal range of MCP flowing from the rumen when feeding a range of contemporary commercial diary rations is shown in the box-and-whisker plot in Figure 2. The daily milk production per cow for the dairy farms in our study is similar to Swanepoel et al. (2015), but average MCP flow was lower (1703 versus $2092 \mathrm{~g} \mathrm{CP} / \mathrm{day}$ ), which may be indicative of dietary factors affecting MCP. However, it is in the range of studies (763 to $1959 \mathrm{~g} \mathrm{CP} /$ day) previously reported in the literature when duodenal samples were collected and MCP flow directly

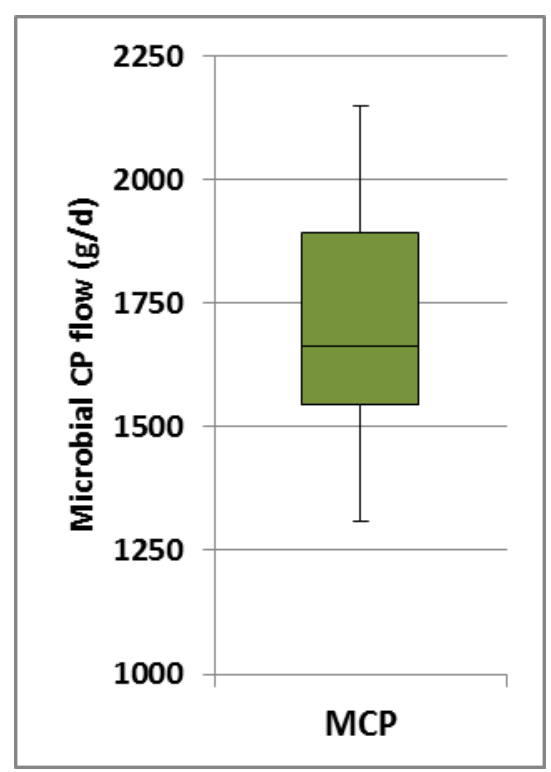

Figure 2. Distribution of estimated microbial crude protein (MCP) flowing from the rumen $(\mathrm{g} / \mathrm{kg})$ with the shaded box indicating the median, upper quartile $\left(80^{\text {th }}\right.$ percentile) and lower quartile $\left(20^{\text {th }}\right.$ percentile $)$ of measured data points and the whiskers representing the maximum and minimum measured data points. 
measured in Holstein cows (Khorasani et al., 1993; Robinson et al., 1994; 1996a and b; 1998; Stensig and Robinson, 1997; Timmermans et al., 2000; González-Ronquillo et al., 2003; Moorby et al., 2006), which suggests that our urine AL estimated MCP flows are biologically sensible.

This MCP data can therefore be used as a guideline of normal MCP values for cows fed contemporary California dairy rations, for use as a benchmark of high vs. low levels in cases where metabolic models are not used to predict MCP outflow, or to evaluate model predictions

of duodenal MCP flow. Thus values outside this range (i.e., not within the $20^{\text {th }}$ to $80^{\text {th }}$ percentile of all data) suggests investigation of reasons for the high or low MCP values is warranted.

There is currently no commercial laboratory that offers AL analysis in urine, even though it would not be difficult to develop since autoanalysers and chromatography methods for PD analyses exist. However our colorimetric urine AL analysis technique is performed on a regular basis at the Animal Nutrition Laboratory at the University of California in Davis.

\subsubsection{Possible drivers of MCP production}

Correlations between MCP flow and some TMR analytes are in Table 4. There were statistically significant slopes between estimated MCP flow from the rumen and the OM and NDF contents of the ration $(P<0.01$ and $P=0.03$ respectively), which are illustrated in Figure 3 a and 3b. The positive correlation of MCP with the OM content in the diet is biologically sensible (Figure 3a), even though the extent of the change seems high. A review summarizing results from 41 experiments and 161 different diets (Clark et al., 1992) showed a strong positive correlation $\left(\mathrm{r}^{2}=0.62\right)$ between $\mathrm{OM}$ intake and MCP flow to the small intestine. 
The positive correlation of MCP outflow with the NDF content of the ration (Figure $3 \mathrm{~b}$ ) confirms the central role of structural carbohydrates in determining MCP flow from the rumen, as higher levels of structural fiber facilitates increased passage of microbes attached to fibrous

Table 4. Microbial protein flow $(\mathrm{g} / \mathrm{d})$ from the rumen as influenced by the nutrient and ingredient profiles of the total mixed rations (TMR; $\mathrm{g} / \mathrm{kg} \mathrm{DM}$ ).

\begin{tabular}{|c|c|c|c|c|c|}
\hline & \multirow[b]{2}{*}{ Intercept } & \multirow[b]{2}{*}{ Slope } & \multicolumn{2}{|c|}{$P$} & \multirow[b]{2}{*}{$\mathrm{r}^{2}$} \\
\hline & & & Intercept $^{1}$ & Slope $^{2}$ & \\
\hline \multicolumn{6}{|l|}{ Nutrient levels of the TMR $(\mathrm{g} / \mathrm{kg})$} \\
\hline Organic matter & -12747 & -158.1 & $<0.01$ & $<0.01$ & 0.46 \\
\hline $\mathrm{NDF}^{3}$ & 102 & 53.5 & 0.88 & 0.03 & 0.25 \\
\hline Crude protein & 2243 & -32.7 & 0.02 & 0.56 & 0.02 \\
\hline $\mathrm{NSC}^{4}$ & 2233 & -13.2 & 0.02 & 0.55 & 0.02 \\
\hline Fat & 1548 & 32.9 & $<0.01$ & 0.63 & 0.01 \\
\hline Starch & 1601 & 5.1 & $<0.01$ & 0.72 & 0.01 \\
\hline \multicolumn{6}{|l|}{ Gas production of the TMR $(\mathrm{g} / \mathrm{kg} O M)$} \\
\hline $4 \mathrm{~h}$ & 3417 & -16.8 & $<0.01$ & 0.11 & 0.14 \\
\hline $24 \mathrm{~h}$ & 1862 & -0.6 & 0.08 & 0.88 & $<0.01$ \\
\hline $30 \mathrm{~h}$ & 1949 & -0.9 & 0.08 & 0.82 & $<0.01$ \\
\hline $48 \mathrm{~h}$ & 1677 & 0.1 & 0.12 & 0.98 & $<0.01$ \\
\hline \multicolumn{6}{|l|}{ Ingredient levels of the $T M R^{5}(\mathrm{~g} / \mathrm{kg})$} \\
\hline Corn, grain & 1405 & 16.8 & $<0.01$ & 0.06 & 0.19 \\
\hline Canola, meal ${ }^{6}$ & 1909 & -26.7 & $<0.01$ & 0.09 & 0.16 \\
\hline Cottonseed, fuzzy upland & 1577 & 22.8 & $<0.01$ & 0.13 & 0.12 \\
\hline Corn, silage & 1573 & 10.1 & $<0.01$ & 0.16 & 0.11 \\
\hline Almond, hulls & 1742 & -5.0 & $<0.01$ & 0.62 & 0.01 \\
\hline Alfalfa, hay & 1737 & -2.1 & $<0.01$ & 0.81 & $<0.01$ \\
\hline Corn distillers grains ${ }^{7}$ & 1701 & 0.4 & $<0.01$ & 0.98 & $<0.01$ \\
\hline \multicolumn{6}{|c|}{$\begin{array}{l}{ }^{1} \text { Probability that the intercept differs from zero. } \\
{ }^{2} \text { Probability that the slope differs from } 1 . \\
{ }^{3} \text { Neutral detergent fiber assayed with heat stable amylase, expressed exclusive of residual ash. } \\
{ }^{4} \text { Non structural carbohydrates calculated as } 100 \text { minus Ash, Fat, CP, NDF (g/kg DM). } \\
{ }^{5} \text { Only ingredients present in more than } 50 \% \text { of TMR were included in the table, except for whey, molasses and } \\
\text { mineral premix which were not included due to low inclusion levels in all TMR. } \\
{ }^{6} \text { Combined solvent and expeller. }\end{array}$} \\
\hline
\end{tabular}

particles thereby increasing MCP outflow (Van Soest, 1994), at least within this range of dietary NDF. The lack of correlation between MCP flow from the rumen and milk production in this dataset (data not shown; $\mathrm{r}^{2}=0.02$ ) is likely due to the narrow range of DIM and milk production 
of the cows (which was our objective). The NRC (2001) recommends an NDF content of 320 $\mathrm{g} / \mathrm{kg}$ for cows producing $40 \mathrm{~kg}$ of milk/day, which is higher than our average of $299 \mathrm{~g} / \mathrm{kg}$. Higher levels of NSC in diets can cause rumen acidosis, especially if there is inadequate NDF, thereby reducing fiber digestion as well as MCP production and outflow. Stokes et al. (1991) reported

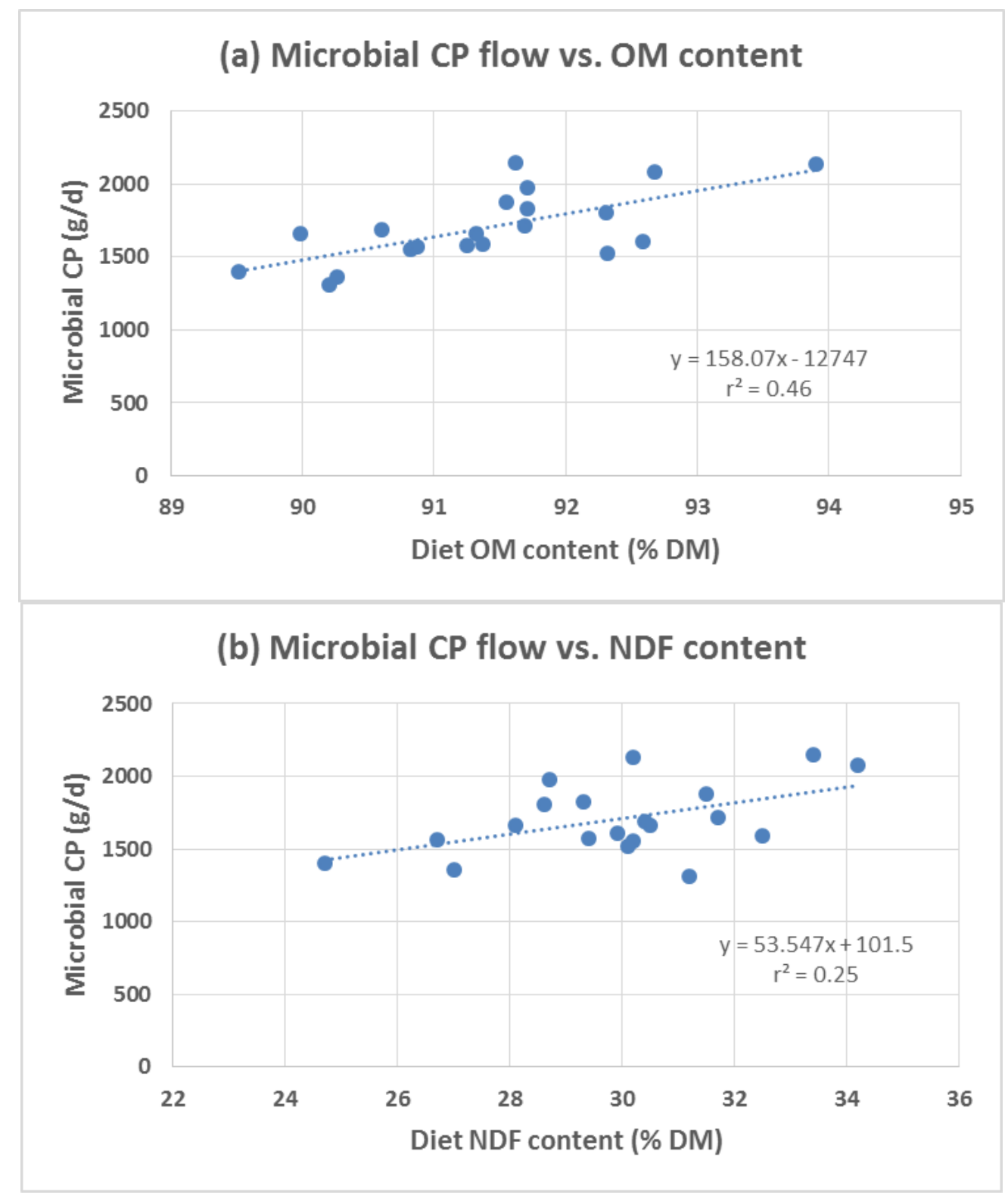

Figure 3. Relationships between the organic matter $(\mathrm{OM})$ and neutral detergent fiber (NDF) content of the TMR on a DM basis to microbial crude protein (MCP) flow $(\mathrm{g} / \mathrm{kg})$ from the rumen in the 20 groups of sampled cows. 
that NSC contents higher than $240 \mathrm{~g} / \mathrm{kg}$ of ration DM enhance MCP flow from the rumen. However the tendency for a negative correlation between MCP flow and the $4 \mathrm{~h}$ gas production $(P=0.11)$ suggests that higher levels of NSC, in the 370 to $450 \mathrm{~g} / \mathrm{kg} \mathrm{DM}$ range in our study, did not support increased MCP flow from the rumen, possibly due to the offsetting lower NDF level in the ration. According to NRC (2001), there is very little benefit to increasing ration NSC above $360 \mathrm{~g} / \mathrm{kg}$ for cows producing $40 \mathrm{~kg}$ milk/day, which could explain why milk production was negatively correlated (Table $5 ; P=0.03$ ) with diet NSC content. This suggests that higher NDF content in the ration, enhancing MCP outflow from the rumen, is more important to milk production than MCP production per se, unless there is reason to believe that ration energy density is limiting production.

Table 5. Milk production $(\mathrm{kg} / \mathrm{d})$ as influenced by the nutrient profile of the total mixed ration $(\mathrm{g} / \mathrm{kg})$.

\begin{tabular}{lccccc}
\hline & & & \multicolumn{2}{c}{$P$} & \\
\cline { 5 - 6 } & & & & & \\
& Intercept & Slope & Intercept $^{1}$ & Slope $^{2}$ & $\mathrm{r}^{2}$ \\
\hline & & & & & \\
Fat & 23.92 & 4.33 & $<0.01$ & $<0.01$ & 0.47 \\
NSC $^{3}$ & 84.34 & -0.99 & $<0.01$ & 0.03 & 0.24 \\
NDF $^{4}$ & 29.66 & 0.49 & 0.09 & 0.38 & 0.04 \\
Crude protein $_{\text {Organic matter }}$ & 28.32 & 0.97 & 0.17 & 0.42 & 0.04 \\
Starch & 83.22 & -0.45 & 0.14 & 0.47 & 0.03 \\
& 44.95 & -0.03 & $<0.01$ & 0.93 & $<0.01$ \\
\hline
\end{tabular}

\footnotetext{
${ }^{1}$ Probability that the intercept differs from zero.

${ }^{2}$ Probability that the slope differs from 1.

${ }^{3}$ Non structural carbohydrates calculated as 100 minus Ash, Fat, CP, NDF (g/kg DM).

${ }^{4}$ Neutral detergent fiber assayed with heat stable amylase, expressed exclusive of residual ash.
}

No other MCP correlations existed with TMR analytes (i.e., $P>0.1$ ) and there were no correlations between MCP flow from the rumen and individual TMR ingredients (i.e., P>0.06). 


\subsection{Determining plasma AA concentrations}

Attempts have been made to establish ideal concentrations of EAA in MP. Methods used to predict limiting AA, and therefore AA requirements, of lactating dairy cows are numerous, including culturing bovine mammary cells in AA mediums to determine effects on milk protein synthesis (Clark et al., 1978; Arriola Apelo et al., 2014b), evaluating changes in plasma AA concentrations and its impacts on milk and milk protein production during intravenous (Fisher, 1972) or post-ruminal supplementation of single or combinations of AA (Clark, 1975; Clark et al., 1978; Schwab et al., 1992a; 1992b; Weekes et al., 2006; Haque et al., 2012; 2013), doseresponse relationships between animal performance and $\mathrm{N}$ inputs (NRC 2001), calculating the extraction efficiency of the mammary gland by determining arteriovenous differences of AA across the mammary gland (Mulrooney et al., 2009; Christen et al., 2010), as well as uptake of AA from the small intestine (and the mammary gland) relative to their output in milk (Piepenbrink et al., 1998). However, results are variable and inconsistent, with some methods using metabolic models to predict AA supplied from experimental rations, and data is interpreted differently amongst researchers with overall levels highly dependent on base rations, which varied amongst experiments. Interpreting plasma AA concentrations from experimental treatments may not relate treatment plasma AA concentrations to contemporary rations formulated under commercial conditions and, since metabolic models inadequately predict degradability of $\mathrm{CP}$ in the rumen and passage of protein and $\mathrm{AA}$ to the intestine, there is a requirement for practical and simple on-farm methods to measure real time plasma AA concentrations in the cows. Thus collecting a blood sample from the tail vein of dairy cows, easily performed on commercial dairy farms, and analyzing concentrations of free AA in plasma provides representation of intestinally absorbed AA and can be used as an index to determine AA availability to the mammary gland and surrounding tissue (Zhang et al., 2016). 


\subsubsection{Ranges of plasma AA concentrations}

The LSD analysis determined that a composite of 6 blood samples/group was adequate to represent a specific group of cows. According to Oetzel (2003) a minimum of 8 cows should be sampled for tests with mean outcomes, which applies to most blood samples. However, our results suggest only 6 samples, perhaps since plasma AA concentrations have relatively low variability. Even with the large variation in ingredients amongst the 20 farms' TMR, the variation in some of the most important plasma AA amongst dairies was small (see the box-andwhisker plots in Figure 4). While it is difficult to compare plasma AA analysis among studies due to variations attributed to laboratory technique, our results compare well to other studies reporting plasma AA concentrations obtained from the same laboratory (Swanepoel et al., 2014; 2015).

Thus these box-and-whisker plots can be used as an index of mean plasma AA values for cows fed contemporary dairy rations, and as a benchmark of high versus low levels in cases where metabolic models are not used to formulate to specific intestinal AA deliveries, or as confirmation of acceptable diet formulation (i.e., when analyzed plasma AA values fall within the $20^{\text {th }}$ to $80^{\text {th }}$ percentile shaded box). However investigation of possible diet formulation issues may be suggested when analyzed plasma AA values are outside of their boxed range, especially for potentially limiting EAA.

Methods to analyse plasma AA are readily available at many commercial laboratories, thereby presenting an opportunity to obtain "real time" profiles of AA available for milk production, without analyzing the rations fed or estimating AA digestibility and/or duodenal AA flow data. 


\subsubsection{Possible drivers of plasma AA concentrations}

\subsubsection{Correlations of plasma AA with MCP flow from the rumen}

Even though it has long been accepted that 40 to $80 \%$ of the AA requirements of lactating cows are supplied by MCP flowing to the small intestine (Sniffen and Robinson, 1987) and that it is a higher quality protein than from most feeds (Schingoethe, 1996), MCP flow from the rumen did not affect plasma AA concentrations. It could be that the contribution of MCP to the total supply of AA is already so large that the variation in MCP among rations led to changes that were too small to matter, and that it is the AA profile of rumen undegradable CP (RUP) that affected plasma profiles. This seems sensible due to the wide range in the feed composition of the TMR among our dairy farms. Due to the relatively narrow CP range of the 20 dairy rations (i.e., $165 \pm$ $2.3 \mathrm{~g} / \mathrm{kg} \mathrm{DM}$ ), it is likely that feeding one protein substitutes for others (Schingoethe, 1996), which was also reported by Clark et al. (1992) where MCP flow to the intestine was not affected by source of protein in the diet, but passage of AA to the intestine were altered, probably due to differences in the AA profiles of the RUP among dietary protein sources.

\subsubsection{Correlations of plasma AA with nutrient profiles of the TMR}

Even though there were no correlations of plasma AA concentrations with dietary $\mathrm{CP}, \mathrm{OM}$, NDF or fat levels (i.e., $\mathrm{r}^{2}<0.16$ ), there were correlations of AA with RUP and starch content of the rations (Table 6).

The lack of correlation of plasma AA levels with ration $\mathrm{CP}$ was expected since the protein provided by the ration is fundamentally changed by microorganisms in the rumen, digesting it and converting much of it to $\mathrm{MCP}$, as well as creating shorter peptide chains and free AA that pass to the lower digestive tract. However, this contradicts Clark et al. (1992) where additional CP increased AA supply to the intestine without affecting MCP synthesis. 
Table 6. Correlations of plasma amino acid concentrations $(\mu \mathrm{g} / \mathrm{mL})$ and the nutrient profile of the diet $(\mathrm{g} / \mathrm{kg} \mathrm{DM})$ of the 20 dairy sites.

\begin{tabular}{|c|c|c|c|c|}
\hline & \multicolumn{2}{|c|}{ RUP $^{1}$} & \multicolumn{2}{|c|}{ Starch } \\
\hline & $P$ Slope $^{2}$ & $r^{2}$ & $P$ Slope $^{2}$ & $r^{2}$ \\
\hline \multicolumn{5}{|c|}{ Essential amino acids (EAA) } \\
\hline Thr & 0.01 & 0.31 & 0.14 & 0.12 \\
\hline $\operatorname{Trp}$ & 0.05 & 0.19 & 0.66 & 0.01 \\
\hline Leu & 0.19 & 0.09 & 0.18 & 0.10 \\
\hline Arg & 0.23 & 0.08 & 0.39 & 0.04 \\
\hline Lys & 0.24 & 0.08 & 0.65 & 0.01 \\
\hline Phe & 0.26 & 0.07 & 0.16 & 0.11 \\
\hline Ile & 0.27 & 0.07 & 0.19 & 0.10 \\
\hline $\mathrm{Val}$ & 0.44 & 0.03 & 0.10 & 0.14 \\
\hline His & 0.47 & 0.03 & 0.04 & 0.22 \\
\hline Met & 0.97 & $<0.01$ & 0.38 & 0.04 \\
\hline Total EAA & 0.39 & 0.04 & 0.29 & 0.06 \\
\hline Ratio Lys:Met & 0.28 & 0.06 & 0.19 & 0.09 \\
\hline \multicolumn{5}{|c|}{ Non-essential amino acids (NEAA) } \\
\hline Gly & 0.03 & 0.23 & 0.14 & 0.12 \\
\hline Ser & 0.04 & 0.21 & 0.02 & 0.25 \\
\hline Ala & 0.06 & 0.18 & 0.05 & 0.20 \\
\hline Tyr & 0.19 & 0.09 & 0.86 & $<0.01$ \\
\hline Gln & 0.19 & 0.09 & 0.03 & 0.23 \\
\hline Asp & 0.74 & 0.01 & 0.87 & $<0.01$ \\
\hline Glu & 0.80 & $<0.01$ & 0.48 & 0.03 \\
\hline Pro & 0.87 & $<0.01$ & 0.47 & 0.03 \\
\hline Total NEAA & 0.09 & 0.15 & 0.02 & 0.27 \\
\hline Total AA & 0.10 & 0.14 & 0.56 & 0.02 \\
\hline
\end{tabular}

\footnotetext{
${ }^{1}$ Rumen undegradable protein. All CP, NDF and Crude fat $\mathrm{r}^{2}<0.16$. Organic matter $\mathrm{r}^{2}<0.2$ (except for ammonia $\left.\mathrm{r}^{2}=0.35\right)$ and so are not listed.

${ }^{2}$ Probability that the slope differs from 1 .
}

A correlation of some AA with RUP level in the ration supports previous findings that outflow of RDP in these rations played a larger role in plasma AA profiles than MCP flow from the rumen per se (Clark et al., 1992). However, Boucher et al. (2007) showed that even though increased dietary RDP contents increase MCP flow to the omasum, it does not change the flow of AA to the omasum. That RUP is negatively correlated to Thr, Trp, Ser and Gly $(P \leq 0.05)$ suggests that the higher RUP contents in some rations, possibly at the expense of MCP, did not supply adequate amounts of these AA. Very little is known about the importance or functions of 
Ser, but it has been linked to cellular energy metabolism as well as production on Gly, Trp and Thr, all of which were negatively correlated $(P \leq 0.05)$ with diet RUP contents. Diet starch content was also correlated with plasma Ser levels, together with Gln $(P \leq 0.03)$, and both AA are linked to cellular energy metabolism, while Ala was correlated to both RUP (negatively; $P=0.06$ ) and starch (positively; $P=0.05$ ). There was also a negative correlation between the diet starch content and plasma His concentration $(P<0.04)$. Since His residues are important components of salivary and pancreatic $\alpha$-amylase with uncertain roles in amyloclastic activity of the amylase enzyme (Ishikawa, et al., 1992; Tseng et al., 1999), this may be due to utilization of His as diet starch contents increased.

As with MCP, no correlation existed between RUP levels and milk production, which may be expected since a 12 year literature review (Santos et al., 1998) examining a wide range of diets and CP contents reported that higher diet RUP contents does not consistently improve lactational performance, even though it changes plasma AA profiles, suggesting that those rations were not deficient in RUP. However there was a positive relationship $(P<0.01)$ between milk production and fat content of the TMR (Table 5) which suggests that energy available to the cows, rather than protein and AA concentrations, were major drivers of milk production. According to a meta-analysis by Rabiee et al. (2012) of TMR fed systems, and a review by Schroeder et al. (2004) of pasture based systems, fat supplementation to the diet of dairy cows always has a positive effect on milk production regardless of the production system or fat saturation profile.

\subsubsection{Correlations of plasma AA with ingredient profiles of the TMR}

As expected, there were correlations between some major TMR ingredients and AA concentrations in the plasma, although most were relatively weak (Table 7). The only ingredients which appeared in all 20 rations were alfalfa hay and canola meal (CM), and the correlations 
were positive for increasing inclusion levels of these ingredients and all the AA in the plasma, except Gly, Gln, Ser and His in the case of alfalfa hay and Phe, Tyr and Leu in the case of CM. This corresponds with the lower concentrations of these AA in the two ingredients. It was interesting that the same AA that were negatively correlated with higher levels of RUP in the ration were also negatively correlated to alfalfa hay inclusion levels in the TMR. Contrary to CM's higher correlation with the total non-essential AA (NEAA; $r^{2}=0.33$ ), alfalfa hay was more correlated with the total EAA $\left(\mathrm{r}^{2}=0.24\right)$. All major corn protein sources (i.e., corn grain, corn

Table 7. Correlations of plasma amino acid concentrations $(\mu \mathrm{g} / \mathrm{mL})$ and the ingredient profile of the diet $(\mathrm{g} / \mathrm{kg}$ TMR DM) of the 20 dairy sites ${ }^{1}$.

\begin{tabular}{cccccc}
\hline & Canola meal & Alfalfa, hay & Corn, grain & $\begin{array}{c}\text { Corn, } \\
\text { silage }\end{array}$ & $\begin{array}{c}\text { Corn distillers } \\
\text { grains }^{3}\end{array}$ \\
\hline Essential amino acids (EAA) & & & & & \\
Lys & & & & & \\
Met & 0.14 & 0.23 & 0.22 & 0.30 & 0.25 \\
His & 0.12 & $<0.01$ & 0.01 & 0.05 & 0.01 \\
Phe & $<0.01$ & 0.02 & 0.11 & 0.02 & 0.04 \\
Leu & 0.08 & 0.08 & 0.08 & 0.08 & 0.09 \\
Val & 0.01 & 0.02 & 0.04 & 0.06 & 0.28 \\
Ile & 0.01 & 0.34 & 0.25 & 0.30 & 0.05 \\
Arg & 0.01 & 0.36 & 0.21 & 0.31 & 0.07 \\
Thr & 0.04 & 0.21 & 0.19 & 0.28 & 0.24 \\
Trp & 0.30 & 0.01 & $<0.01$ & 0.02 & 0.19 \\
Total EAA & 0.08 & 0.28 & $<0.01$ & 0.02 & 0.38 \\
Ratio Lys:Met & 0.04 & 0.24 & 0.18 & 0.26 & 0.04 \\
Non-essential amino acids (NEAA) & $<0.01$ & 0.20 & 0.31 & 0.14 & 0.30 \\
Tyr & & & & & \\
Gln & & & & & 0.29 \\
Glu & 0.01 & $<0.01$ & 0.01 & 0.02 & $<.02$ \\
Ala & 0.27 & 0.11 & 0.01 & $<0.01$ & 0.02 \\
Ser & $<0.01$ & 0.08 & 0.09 & $<0.01$ & $<0.01$ \\
Gly & 0.20 & 0.02 & 0.05 & $<0.01$ & 0.11 \\
Asp & 0.28 & 0.03 & 0.05 & 0.04 & 0.10 \\
Pro & 0.29 & 0.16 & 0.04 & $<0.01$ & 0.12 \\
Total NEAA & 0.01 & 0.31 & 0.06 & 0.02 & 0.01 \\
Total AA & 0.03 & 0.13 & 0.02 & 0.08 & $<0.01$ \\
Ammonia & 0.33 & 0.03 & 0.06 & $<0.01$ & 0.04 \\
& 0.23 & 0.05 & 0.02 & 0.14 & 0.07 \\
\hline & 0.07 & 0.15 & 0.05 & 0.04 & $<0.01$ \\
\hline & & & & & \\
\hline
\end{tabular}

${ }^{1}$ Values reported are $\mathrm{r}^{2}$.

${ }^{2}$ Combined solvent and expeller.

${ }^{3}$ Combined wet and dry. 


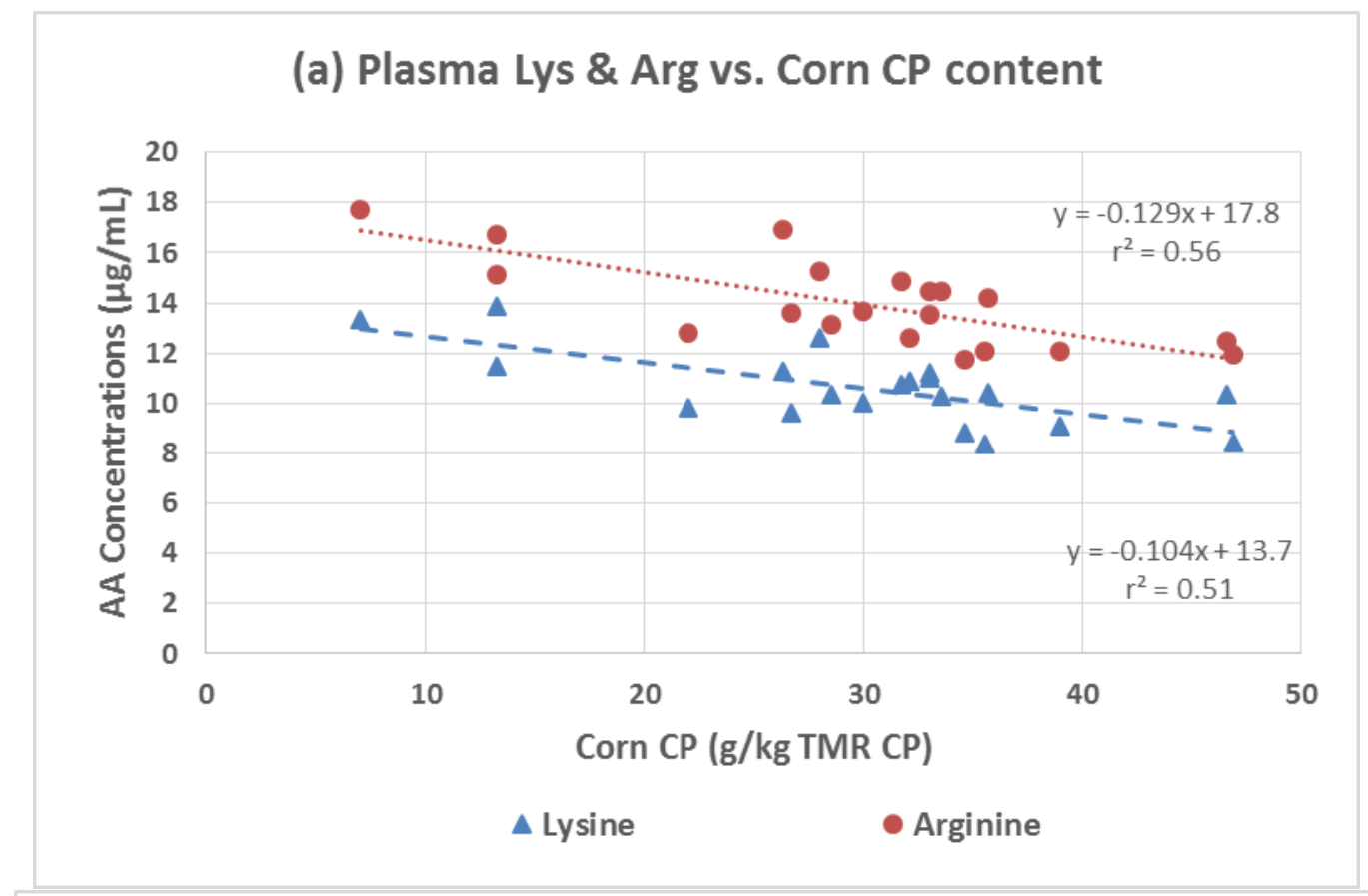

(b) Milk production vs. Corn CP content

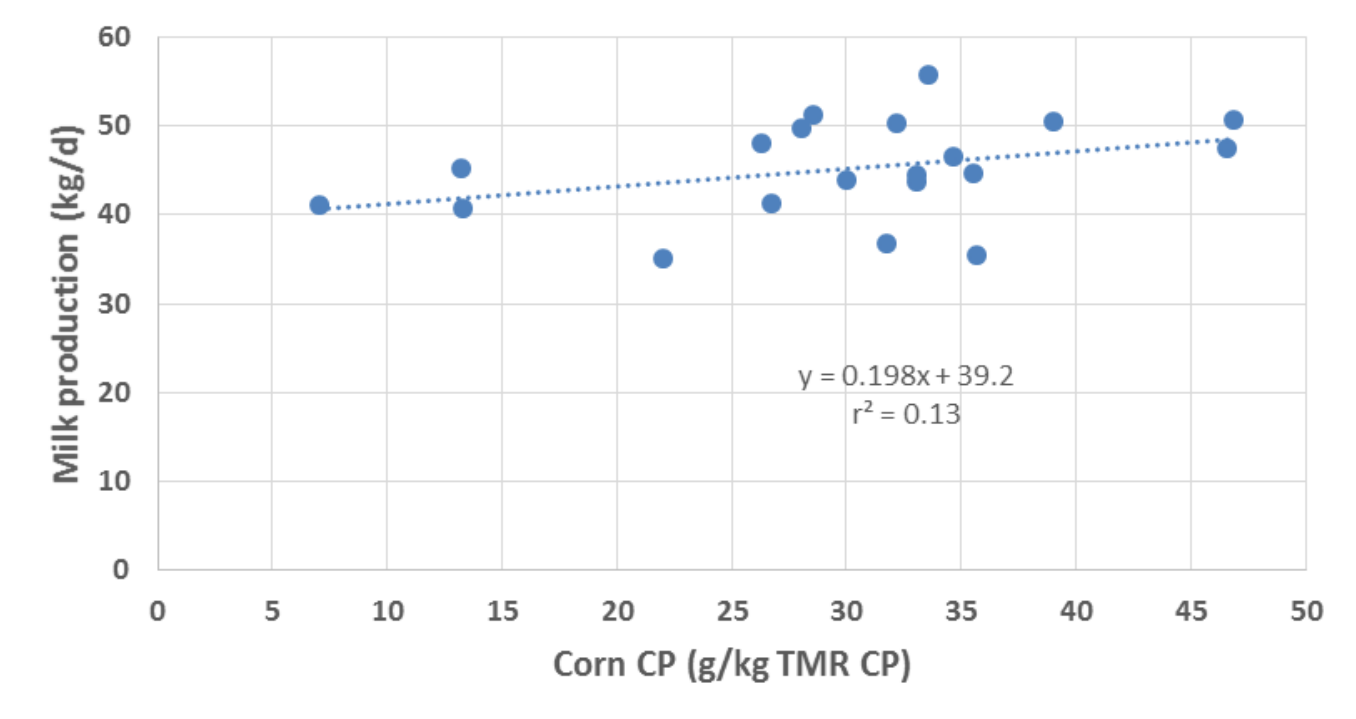

Figure 5. Relationship between the contribution of corn crude protein $(\mathrm{CP})$ to total TMR $\mathrm{CP}(\mathrm{g} / \mathrm{kg} \mathrm{CP})$ and plasma AA concentrations $(\mu \mathrm{g} / \mathrm{ml})$ and milk production $(\mathrm{kg} / \mathrm{d})$ in the 20 groups of sampled cows.

silage, corn distillers grains) had a biologically sensible negative relationship with plasma Lys $\left(r^{2}=0.22,0.30\right.$ and 0.25 respectively) when included at higher levels in the TMR. Indeed a strategic review (Robinson, 2010) suggested that Lys becomes the limiting AA when high levels of corn $\mathrm{CP}$ are fed, which is consistent with Figure 5a. In addition, high dietary corn CP inclusion levels also had a strong negative correlation $\left(\mathrm{r}^{2}=0.56\right)$ with plasma Arg concentrations. 


\subsubsection{Correlations of plasma AA with milk production}

There were no correlations between any plasma AA and milk production. Even Lys, Met and the Lys:Met ratio had a poor relationship (i.e., $P>0.60$ ) with milk production (Figure 6a and 6b).

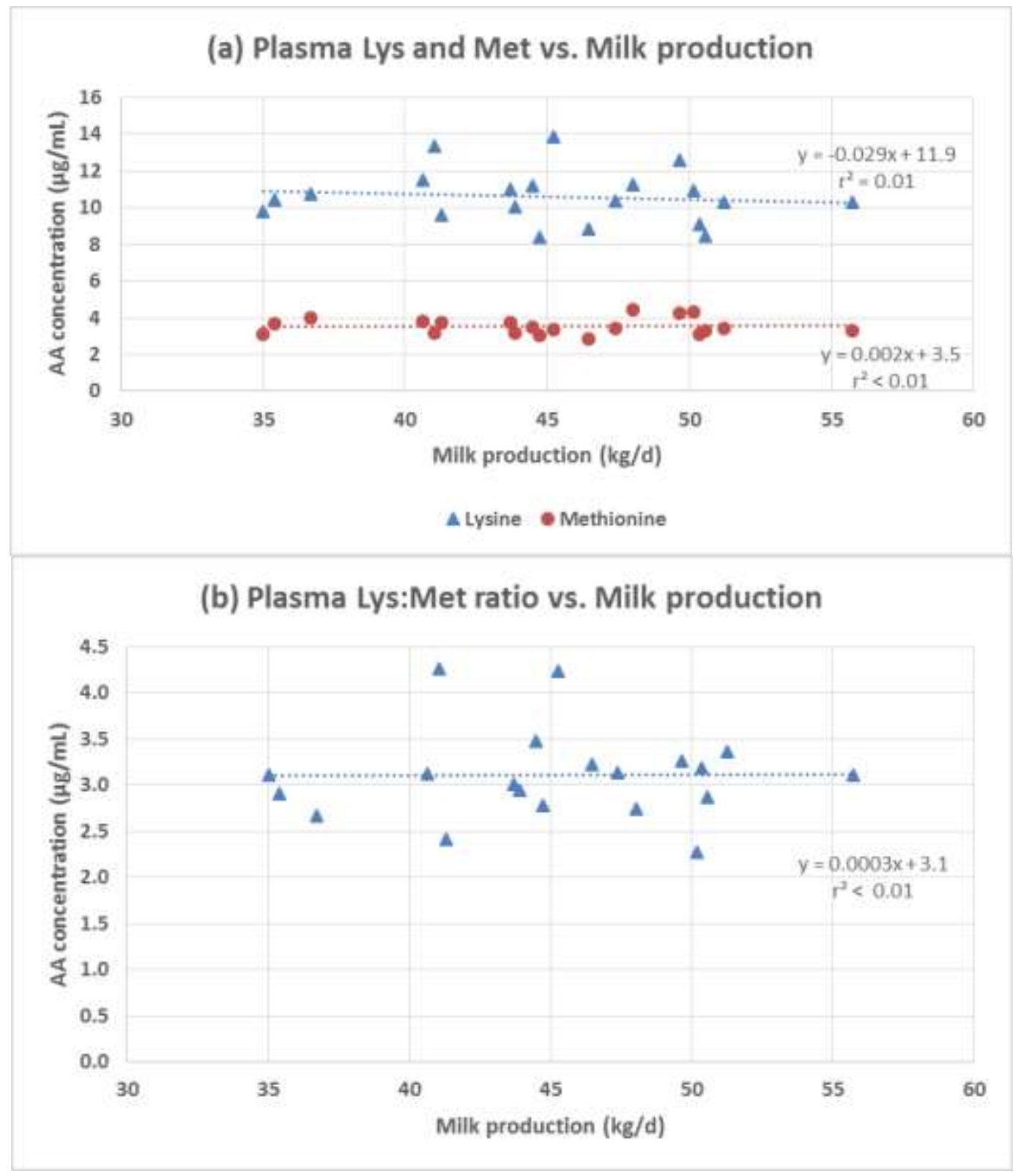

Figure 6. Relationship between methionine (Met), lysine (Lys) and their ratio to milk production (kg/d) in the 20 groups of sampled cows.

This supports previous findings summarized by Swanepoel et al. (2015) showing that the theoretical optimum Lys:Met ratio of 3:1 (Chalupa and Sniffen, 2006) does not necessarily 
improve milk production, again speaking to the unsuccessful attempts to establish ideal concentrations of EAA in dairy cattle diets. However, contrary to expectation, even with corn CP contributions as high as $470 \mathrm{~g} / \mathrm{kg}$ of total TMR $\mathrm{CP}$, it had a slight positive correlation $\left(\mathrm{r}^{2}=0.13\right)$ with milk production (Figure $5 \mathrm{~b}$ ). This concurs with the suggestion that ration formulations by dairy consultants include complementary CP sources that offset imbalances in AA profiles, and that the lack of a negative impact from low Lys plasma levels could be due to an increased contribution from MCP (which is higher in Lys than any dietary protein source) to total protein absorbed by the cows.

\subsubsection{Inter-correlations of plasma $A A$}

Correlations amongst many plasma AA concentrations (Figure 7) resembles the network of interactions which have been documented among nutritionally important minerals (e.g., Jurgens

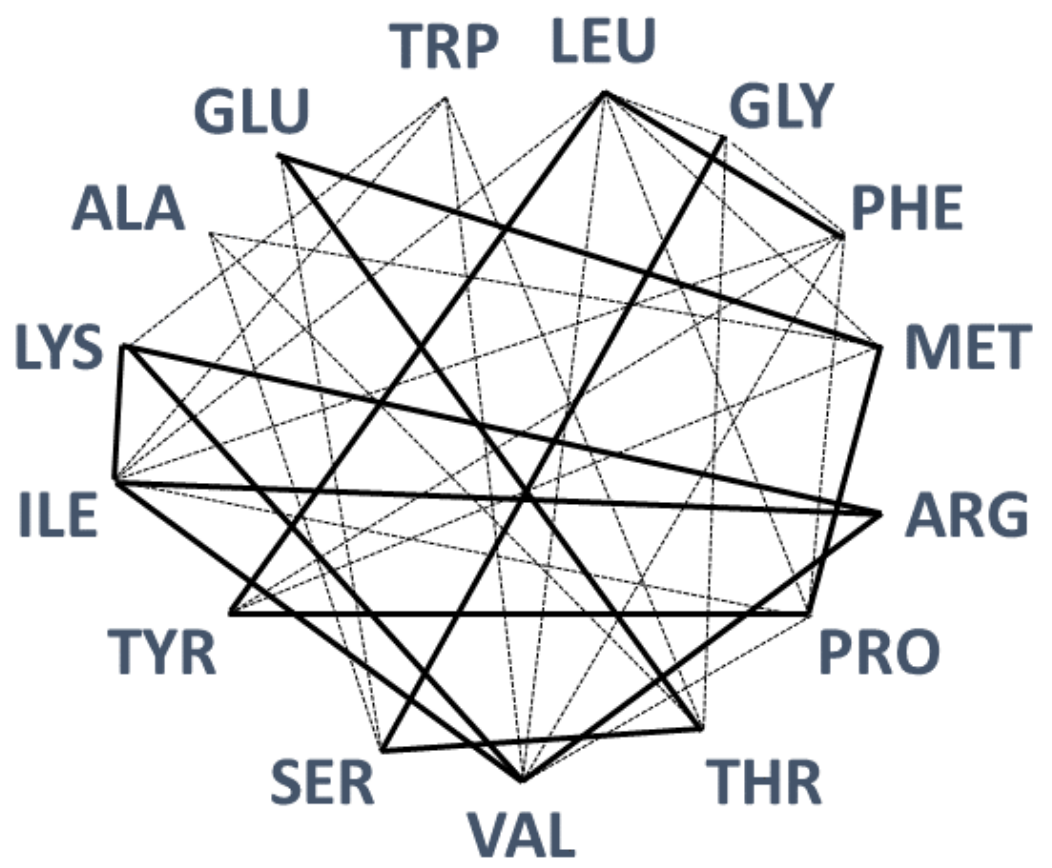

Figure 7. Relationships between plasma AA in the 20 groups of sampled cows. Dotted lines $r^{2}=0.20-0.49$, solid lines $r^{2}>0.50$ 
et al., 2012). This supports the suggestion by Swanepoel et al. (2015) that AA are bioactive molecules that should be considered in total, rather than individually, while also considering antagonisms and interactions amongst them (Haque et al., 2013). Such factors may explain the

inconsistency of data obtained from studies that have supplemented ruminally protected AA and/or attempt to change the AA profile of intestinally delivered protein (Robinson, 2010). The AA involved in the most interactions with other AA were the branched-chain AA Ile, Val and Leu, as well as Met and Phe.

Two AA that should be considered in combination are Phe and Tyr since conversion of Phe to Tyr in the liver is regarded an obligatory step when Phe is catabolized and, since Phe is the primary source of Tyr, this makes it a conditionally EAA (Matthews, 2007). This was confirmed since Phe and Tyr were positively correlated $\left(r^{2}=0.48\right.$; Figure 8$)$.

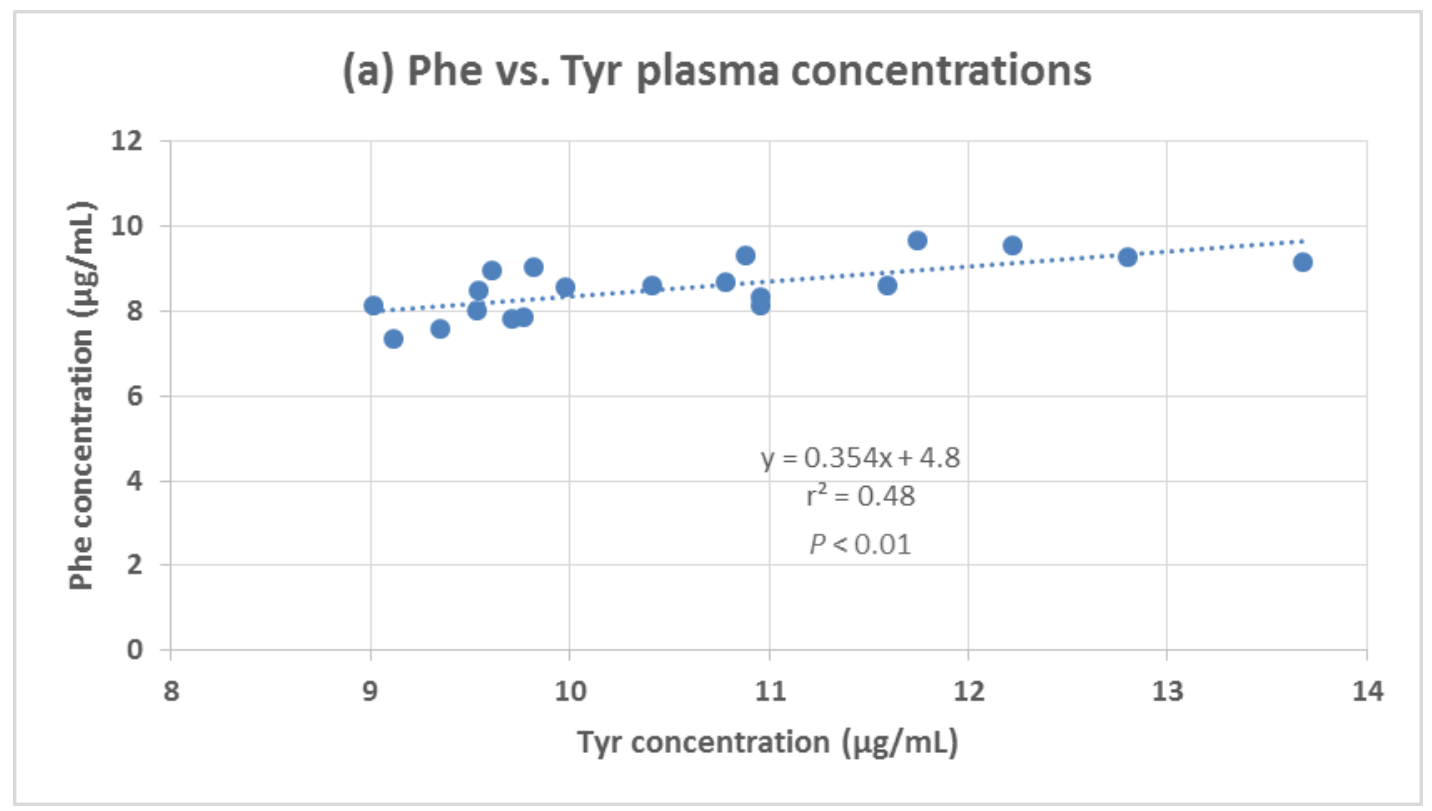

Figure 8. Relationship between Phenylalanine (Phe) and Tyrosine (Tyr) in the 20 groups of sampled cows. 


\section{Conclusions}

This database can be used as a benchmark for well managed dairy farms to compare high, low and mean levels of estimated MCP flow from the rumen and plasma AA concentrations, or as a real time index of normal $\mathrm{MCP}$ and $\mathrm{AA}$ values when models are not used in feed formulation. They could also be used to confirm acceptable diet formulation or to investigate possible formulation issues related to rumen microbial growth and/or absorbable AA issues in commercial groups of lactating dairy cows. It also provides a database to help interpret and assess experimental study treatment levels of MCP and plasma AA using similar methods and cows, and to aid in determining the biological sensibility of these values under such conditions. However because within-day and between-day variation was not considered in our study, appropriate biological caution is advised in using this approach for evaluation of formulated rations.

\section{Acknowledgements}

The authors thank all the dairies and nutritional consultants that participated for their interest, assistance and patience during the completion of the study.

\section{Conflict of Interest}

The authors declare that they have no conflict of interest in this study.

\section{References}

AOAC 2005. Official methods of analysis of AOAC International, 18th ed. Association of official Analytical Chemists International, Gaithersburg, MD, USA. 
AOAC 2006. Official methods of analysis of AOAC International, $18^{\text {th }}$ ed., AOAC International, Arlington, VA, USA.

Arriola Apelo, S.I., Bell, A.L., Estes, K., Ropelewski, J., de Veth, M.J., Hanigan, M.D. 2014a. Effects of reduced dietary protein and supplemental rumen-protected essential amino acids on the nitrogen efficiency of dairy cows. J. Dairy Sci. 97, 5688-5699.

Arriola Apelo, S.I., Singer, L.M., Ray, W.K., Helm, R.F., Lin, X.Y., McGilliard, M.L., St-Pierre, N.R., Hanigan, M.D. 2014b. Casein synthesis is independently and additively related to individual essential amino acid supply. J. Dairy Sci. 97, 2998-3005.

Bateman, H.G., Clark, J.H., Patton, R.A., Peel, C.J., Schwab, C.G. 2001a. Accuracy and precision of computer models to predict passage of crude protein and amino acids to the duodenum of lactating cows. J. Dairy Sci. 84, 649-664.

Bateman, H.G., Clark, J.H., Patton, R.A., Peel, C.J., Schwab, C.G. 2001b. Prediction of crude protein and amino acid passage to the duodenum of lactating cows by models compared with in vivo data. J. Dairy Sci. 84, 665-679.

Boucher, S.E., Ordway, R.S., Whitehouse, N.L., Lundy, F.P., Kononoff, P.J., Schwab, C.G. 2007. Effect of incremental urea supplementation of a conventional corn silage-based diet on ruminal ammonia concentration and synthesis of microbial protein. J. Dairy Sci. 90, 56195633.

Burgos, S.A., Robinson, P.H., Fadel, J.G., DePeters, E.J. 2005. Ammonia volatilization potential: Prediction of urinary urea nitrogen output in lactating dairy cows. Agric. Ecosyst. Environ. 111, 261-269.

Chalupa, W., Sniffen, C. 2006. Balancing rations on the basis of amino acids: The CPM-Dairy approach. Proc. 21st Annual Southwest nutrition and management conference, Tempe, AZ, February 23-24, pp. 96-109. 
Chen, X.B., Gomes, M.J. 1992 (Edited and reprinted 1995). Estimation of microbial protein supply to sheep and cattle based on urinary excretion of purine derivatives - An overview of the technical details. Int. Feed Res. Unit, Occasional Publ. Rowett Research Institute, Aberdeen, UK. http://www.macaulay.ac.uk/IFRU/pdf/chema.pdf (accessed 11 Sept 2014).

Chen, X.B., Ørskov, E. R. 2004. Research on urinary excretion of purine derivatives in ruminants: Past, Present and future. In: Estimation of microbial supply in ruminants using urinary purine derivatives. Kluwer Academic publishers. Makkar, H.P.S., Harinder, P.S., Chen, X.B. (Eds.). p. 180-210.

Chizzotti, M.L., Valadares Filho, S.C., Valadares, R.F.D., Chizzotti, F.H.M., Tedeschi, L.O., 2008. Determination of creatinine excretion and evaluation of spot urine sampling in Holstein cattle. Livest. Sci. 113, 218-225.

Christen, K.A., Schingoethe, D.J., Kalscheur, K.F., Hippen, A.R., Karges, K.K., Gibson, M.L. 2010. Response of lactating dairy cows to high protein distillers grains or 3 other protein supplements. J. Dairy Sci. 93, 2095-2104.

Clark, J.H. 1975. Lactational responses to postruminal administration of proteins and amino acids. J. Dairy Sci. 58, 1178-1197.

Clark, J.H., Klusmeyer, T.H., Cameron, M.R. 1992. Microbial protein synthesis and flows of nitrogen fractions to the duodenum of dairy cows. J. Dairy Sci. 75, 2304-2323.

Clark, R.M., Chandler, P.T., Park, C.S. 1978. Limiting amino acids for milk protein synthesis by bovine mammary cells in culture. J. Dairy Sci. 61, 408-413.

Cone, J.W., van Gelder, A.H., Driehuis, F. 1997. Description of gas production profiles with a three-phasic model. Anim. Feed Sci. Technol. 66, 31-45.

Dewhurst, R.J., Mitton, A.M., Offer, N.W., Thomas, C. 1996. Effects of the composition of grass silage on milk production and nitrogen utilization by dairy cows. Anim. Sci. 62, 25-34. 
Doepel, L., Pacheco, D., Kennelly, J.J., Hanigan, M.D., Lopez, I.F., Lapierre, H. 2004. Milk protein synthesis as a function of amino acid supply. J. Dairy Sci. 87, 1279-1297.

Ferguson, J.D., Galligan, D.T., Thomsen, N. 1994. Principal descriptors of body condition score in Holstein cows. J. Dairy Sci. 77, 2695-2703.

Fisher, L.J. 1972. Response of lactating cows to the intravenous infusion of amino acids. Can. J. Anim. Sci. 52, 377-384.

Gonzalez-Ronquillo, M., Balcells, J., Guada, J.A., Vicente, F. 2003. Purine derivative excretion in dairy cows: Endogenous excretion and the effect of exogenous nucleic acid supply. J. Dairy Sci. 86, 1282-1291.

Hanigan, M.D., Crompton, L.A., Metcalf, J.A., France, J. 2001. Modelling mammary metabolism in the dairy cow to predict milk constituent yield, with emphasis on amino acid metabolism and milk protein production: Model construction. J. Theor. Biol. 213, 223-239.

Haque, M.N., Rulquin, H., Andrade, A., Faverdin, P., Peyraud, J.L., Lemosquet, S. 2012. Milk protein synthesis in response to the provision of an "ideal" amino acid profile at 2 levels of metabolizable protein supplies in dairy cows. J. Dairy Sci. 95, 5876-5887.

Haque, M.N., Rulquin, H., Lemosquet, S. 2013. Milk protein responses in dairy cows to changes in postruminal supplies of arginine, isoleucine, and valine. J. Dairy Sci. 96, 420-430.

Holter, J.B., Urban, W.E. 1992. Water partitioning and intake prediction in dry and lactating Holstein cows. J. Dairy Sci. 75, 1472-1479.

Ishikawa, K., Matsui, I., Honda, K., Nakatani, H. 1992. Multi-functional roles of a histidine residue in human pancreatic alpha-amylase. Biochem. Biophys. Res. Commun. 183, 286-291.

Jurgens, M., Bregendahl, K., Coverdale, J., Hansen, S. 2012. Nutrients and digestive systems. Review of nutrients and digestion. In: Animal feeding and nutrition. $11^{\text {th }}$ Rev. Ed., Kendall Hunt publishing company, Dubuque, IA, USA. P. 51-52. 
Khorasani, G.R., Robinson, P.H. and Kennelly, J.J. 1993. Effects of canola meal treated with acetic acid on rumen degradation and intestinal digestibility in lactating dairy cows. J. Dairy Sci. 76, 1607-1616.

Khorasani, G.R., Robinson, P.H. and Kennelly, J.J. 1994. Evaluation of solvent and expeller linseed meals as protein sources for dairy cattle. Can. J. Anim. Sci. 74, 479-485.

Krishnamoorthy, U., Muscato, T.V., Sniffen, C.J., Van Soest, P.J. 1982. Nitrogen fractions in selected feedstuffs. J. Dairy Sci. 65, 217-225.

Krishnamoorthy, U., Sniffen, C.J., Stern, M.D., Van Soest, P.J. 1983. Evaluation of a mathematical model of rumen digestion and an in vitro simulation of rumen proteolysis to estimate the rumen-undegraded nitrogen content of feedstuffs. Br. J. Nutr. 50, 555-568.

Lee, C., Giallongo, F., Hristov, A.N., Lapierre, H., Cassidy, T.W., Heyler, K.S., Varga, G.A., Parys, C. 2015. Effect of dietary protein level and rumen-protected amino acid supplementation on amino acid utilization for milk protein in lactating dairy cows. J. Dairy Sci. 98, 1885-1902.

Matthews, D.E. 2007. An overview of phenylalanine and tyrosine kinetics in humans. J. Nutr. 137 (6 Suppl 1), 1549-1575.

Menke, K.H., Steingass, H. 1988. Estimation of the Energetic Feed Value Obtained from Chemical Analysis and In Vitro Gas Production Using Rumen Fluid. Anim. Res. Dev. 28, 755.

Moorby, J.M., Dewhurst, R.J., Evans, R.T., Danelon, J.L. 2006. Effects of dairy cow diet forage proportion on duodenal nutrient supply and urinary purine derivative excretion. J. Dairy Sci. $89,3552-3562$.

Mulrooney, C.N., Schingoethe, D.J., Kalscheur, K.F., Hippen, A.R. 2009. Canola meal replacing distillers grains with solubles for lactating dairy cows. J. Dairy Sci. 92, 5669-5676. 
National Research Council. 2001. Nutrient requirements of dairy cattle. 7th Rev. Ed., National Academy Press, Washington, DC, USA.

NFTA 2006. Moisture Task Force Report, 2.2.2.5 Laboratory Dry Matter by Oven Drying for 3 hours at $105^{\circ} \mathrm{C}$, pp. 1-3. http://www.foragetesting.org/files/NFTAReferenceMethodDM-0918-06.pdf (accessed 11 Sept 2014).

Oetzel, G.R. 2003. Herd-based biological testing for metabolic disorders. Advances in Dairy Technology 15:275-285 (Proceedings of the 2003 Western Canadian Dairy Seminar) and Proceedings, Dairy Herd Problems Investigation Seminar, $36^{\text {th }}$ Annual Meeting of the American Association of Bovine Practitioners, Columbus, $\mathrm{OH}$.

Pacheco, D., Patton, R.A., Parys, C., Lapierre, H. 2012. Ability of commercially available dairy ration programs to predict duodenal flows of protein and essential amino acids in dairy cows. J. Dairy Sci. 95, 937-963.

Patton, R.A. 2010. Effect of rumen-protected methionine on feed intake, milk production, true milk protein concentration, and true milk protein yield, and the factors that influence these effects: A meta-analysis. J. Dairy Sci. 93, 2105-2118.

Piepenbrink, M.S., Schingoethe, D.J., Brouk, M.J., Stegeman, G.A. 1998. Systems to evaluate the protein quality of diets fed to lactating cows. J. Dairy Sci. 81, 1046-1061.

Rabiee, A.R., Breinhild, K., Scott, W., Golder, H.M., Block, E., Lean, I.J. 2012. Effect of fat additions to diets of dairy cattle on milk production and components: A meta-analysis and meta-regression. J. Dairy Sci. 95, 3225-3247.

Rauch, R.E., Robinson, P.H., Erasmus, L.J. 2012. Effects of sodium bicarbonate and calcium magnesium carbonate supplementation on performance of high producing dairy cows. Anim. Feed Sci. Technol. 177, 180-193. 
Robinson, P.H. 2010. Impacts of manipulating ration metabolizable lysine and Met levels on the performance of lactating dairy cows: A systematic review of the literature. Livest. Sci. 127, 115-126.

Robinson, P.H. Campbell Mathews, M., Fadel, J.G. 1999. Influence of storage time and temperature on in vitro digestion of neutral detergent fibre at $48 \mathrm{~h}$, and comparison to $48 \mathrm{~h}$ in sacco neutral detergent fibre digestion. Anim. Feed Sci. Technol. 80, 257-266.

Robinson, P.H., Fadel, J.G., Ivan, M. 1996a. Critical evaluation of diaminopimelic acid and ribonucleic acid as markers to estimate rumen pools and duodenal flows of bacterial and protozoal nitrogen. Can. J. Anim. Sci. 76, 587-597.

Robinson, P.H., Givens, D.I., Getachew, G. 2004. Evaluation of NRC, UC Davis and ADAS approaches to estimate the metabolizable energy values of feeds at maintenance energy intake from equations utilizing chemical assays and in vitro determinations. Anim. Feed Sci. Technol. 114, 75-90.

Robinson, P.H., Khorasani, G.R., Kennelly, J.J. 1994. Forestomach and whole tract digestion in lactating dairy cows fed increasing levels of canola meal treated with acetic acid. J. Dairy Sci. $77,552-559$.

Robinson, P.H., Khorasani, G.R., Kennelly, J.J. 1996b. Evaluation of linseed meal for dairy cows: Interaction with grain source on forestomach and whole-tract digestion. Can. J. Anim. Sci. 76, 209-214.

Robinson, P.H., Meyer, D. 2010. Total mixed ration (TMR) sampling protocol. ANR Publication 8413, ANR Publications, University of California, Berkeley, CA, USA.

Robinson, P.H., Sniffen, C.J., and Van Soest, P.J. 1985. Influence of feed intake on digestion and microbial yield in the forestomachs of dairy cattle. Can. J. Anim. Sci. 65,: 437-444. 
Robinson, P.H., Swanepoel, N., Shinzato, I, Juchem, S.O. 2011. Productive responses of lactating dairy cattle to supplementing high levels of ruminally protected lysine using a rumen protected technology. Anim. Feed Sci. Technol. 168, 30-41.

Robinson, P.H., Veira, D.M., Ivan, M. 1998. Influence of supplemental protein quality on rumen fermentation, rumen microbial yield, forestomach digestion, and intestinal amino acid flow in late lactation Holstein cows. Can. J. Anim. Sci. 78, 95-105.

Rulquin, H., Verite, R. 1993. Amino acid nutrition of dairy cows: Productive effects and animal requirements. In: Recent Advances in Animal Production. Proc. Of $27^{\text {th }}$ University of Nottingham Feed Manufacturer's Conference. pp 55-77.

Santos, F. A., Santos, J.E., Theurer, C.B., Huber, J.T. 1998. Effects of rumen-undegradable protein on dairy cow performance: A 12-year literature review. J. Dairy Sci. 81, 3182-3213.

SAS Institute Inc., SAS/STAR® Software: Changes and enhancements, Release 9.4. 2012. SAS Institute Inc., Cary, NC, USA.

Schingoethe, D.J. 1996. Balancing the amino acid needs of the dairy cow. Anim. Feed Sci. Technol. 60, 153-160.

Schroeder, G.F., Gagliostro, G.A., Bargo, F., Delahoy, J.E., Muller, L.D. 2004. Effects of fat supplementation on milk production and composition by dairy cows on pasture: a review. Livestock Sci. 86, 1-18.

Schwab, C.G., Bozak, C.K., Whitehouse, N.L., Mesbah, M.M.A. 1992a. Amino acid limitation and flow to duodenum at four stages of lactation. 1. Sequence of lysine and methionine limitation. J. Dairy Sci. 75, 3486-3502.

Schwab, C.G., Bozak, C.K., Whitehouse, N.L., Olson, V.M. 1992b. Amino acid limitation and flow to duodenum at four stages of lactation. 2. Extent of lysine limitation. J. Dairy Sci. 75, $3503-3518$ 
Smith, D. 1969. Removing and Analyzing Total Non-structural Carbohydrates from Plant Tissue. Wisconsin Agric. Exp. Sta. Res. Report 41.

Sniffen, C.J., Robinson, P.H. 1987. Symposium: Protein and fiber digestion, passage, and utilization in lactating cows. J. Dairy Sci. 70, 425-441.

Stensig, T., Robinson, P.H. 1997. Digestion and passage kinetics of forage fiber in dairy cows as affected by fiber-free concentrate in the diet. J. Dairy Sci. 80, 1339-1352.

Stokes, S.R., Hoover, W.H., Miller, T.K., Blauweikel, R. 1991. Ruminal digestion and microbial utilization of diets varying in type of carbohydrate and protein. J. Dairy Sci. 74, 871-881.

Swanepoel, N., Robinson, P.H., Erasmus, L.J. 2010a. Amino acid needs of lactating dairy cows: Impact of feeding lysine in a ruminally protected form on productivity of lactating dairy cows. Anim. Feed Sci. Technol. 157, 79-94.

Swanepoel, N., Robinson, P.H., Erasmus, L.J. 2010b. Amino acid needs of lactating dairy cows: Predicting limiting amino acids in contemporary rations fed to high producing dairy cattle in California using metabolic models. Anim. Feed Sci. Technol. 161, 103-120.

Swanepoel, N., Robinson, P.H., Erasmus, L.J. 2014. Determining the optimal ratio of canola meal and high protein dried distillers grain protein in diets of high producing Holstein dairy cows. Anim. Feed Sci. Technol. 189, 41-53.

Swanepoel, N., Robinson, P.H., Erasmus, L.J. 2015. Effects of ruminally protected methionine and/or phenylalanine on performance of high producing Holstein cows fed rations with very high levels of canola meal. Anim. Feed Sci. Techn. 205, 10-22.

Timmermans Jr., S.J., Johnson, L.M., Harrison, J.H., Davidson, D. 2000. Estimation of the flow of microbial nitrogen to the duodenum using milk uric acid and allantoin. J. Dairy Sci. 83, 1286-1299. 
Tseng, C-C., Miyamoto, M., Ramalingam, K., Hemavathy, K.C., Levine, M.J., Ramasubbu, N. 1999. The roles of histidine residues at the starch-binding site in streptococcal-binding activities of human salivary amylase. Arch. Oral Biol. 44, 119-127.

Van Soest, P.J. 1994. Nutritional ecology of the ruminant. $2^{\text {nd }}$ Rev. Ed., Cornell University press, Ithica, NY, USA.

Weeks, T.L., Luimes, P.H., Cant, J.P. 2006. Responses to amino acid imbalances and deficiencies in lactating dairy cows. J. Dairy Sci. 89, 2177-2187.

Zhang, Y.D., Bu, D.P., Li, S.C., Zheng, N., Zhou, X.Q., Zhao, M., Zhao, S.G., Li, S.L., Wang, J.Q. 2016. Technical Note: Can tail arterial or tail venous blood represent external pudic arterial blood to measure amino acid uptake by mammary gland of cows? Livest. Sci. 188, 912. 